JERZY GAUL

Archiwum Główne Akt Dawnych w Warszawie

\title{
JÓZEF PIŁSUDSKI WOBEC WYBORÓW DO PARLAMENTU AUSTRIACKIEGO ORAZ DZIAŁALNOŚCI POLSKICH POSŁÓW SOCJALISTYCZNYCH IX KADENCJI (1897-1900)
}

Abstrakt: Józef Piłsudski w młodości zmagał się z carskim despotyzmem i poszukiwał alternatywnych rozwiązań dla Polski, m.in. w konstytucyjnej monarchii habsburskiej. Wyrazem tego były kontakty od $1892 \mathrm{r}$. z socjalistami z zaboru austriackiego, wspieranie ich w kampanii wyborczej w 1897 do V kurii Izby Posłów Rady Państwa w Wiedniu i współpraca z posłami socjalistycznymi z Galicji w latach 1897-1900.

Słowa kluczowe: socjalizm, parlamentaryzm, Rada Państwa w Wiedniu, Józef Piłsudski, Galicja.
Abstr act: In his youth, Józef Piłsudski struggled with tsarist despotism and sought for alternative solutions for Poland, inter alia in the constitutional Habsburg monarchy. To this end, from 1892 he maintained contacts with socialists from Galicia (the Austrian share of the partitioned Polish lands), he supported them in the electoral campaign of 1897 to the fifth curia of the Imperial Council in Vienna, and cooperated with socialist deputies from Galicia in 1897-1900.

Keywords: socialism, parliamentarism, Imperial Council in Vienna, Józef Piłsudski, Galicia.

Trzy ważne rocznice przypadające w latach 2017-2019: sto pięćdziesiąta rocznica urodzin Józefa Piłsudskiego (5 XII 2017), stulecie odzyskania niepodległości (11 XI 2018) i stulecie pierwszych powszechnych wyborów do sejmu (26 I 2019) są okazją do przypomnienia dokonań tego wybitnego i kontrowersyjnego męża stanu, wymykającego się łatwej hagiografii i bezwzględnemu potępieniu. Życie wybitnych ludzi często biegnie w różnym rytmie i różnych kierunkach. Dobro miesza się ze złem, sława przegrywa często z zapomnieniem, osiągnięcia z porażkami. Co określa bardziej biografię bohatera - jego wzloty czy upadki, sukcesy czy klęski? Czy o Napoleonie można mówić wyłącznie jako o cesarzu i tyranie, 
przegranym wodzu i wygnańcu na Elbie, skoro w młodości był republikaninem i błyskotliwym generałem? Podobne dylematy pojawiają się przy ocenie postaci Piłsudskiego. Czy można widzieć w nim tylko samotnika z Sulejówka, autora zamachu majowego i dyktatora zwalczającego parlamentaryzm oraz posłów opozycji, skoro w młodości był zwolennikiem zachodnioeuropejskiego systemu politycznego: konstytucjonalizmu, parlamentaryzmu oraz podstawowych praw obywatelskich, które wcielił w życie jako Naczelnik Państwa?

Młodzieńcze lata w życiu Piłsudskiego warte są przypomnienia i analizy, gdyż był to okres nie tylko jego uporczywych zmagań z carskim despotyzmem, ale także poszukiwań alternatywnych rozwiązań społeczno-politycznych dla Polski. Po aresztowaniu w 1887 r. przez władze carskie i wyroku skazującym na wygnanie na Syberię Piłsudski wyleczył się gruntownie „z resztek ówczesnego rosyjskiego wpływu” i w ten sposób oczyścił sobie „drogę dla wpływów zachodnioeuropejskich”. Stojąc na czele redakcji „Robotnika”, wielokrotnie dawał wyraz swojemu przekonaniu o potrzebie budowy niepodległego państwa polskiego o demokratycznych instytucjach politycznych, w tym parlamentu, dzięki którym możliwa będzie stopniowa realizacja celów socjalistycznych ${ }^{2}$. Przeszkodą w realizacji tych planów był „mur chiński, którym carat odgradza nas od reszty świata, to wykluczenie nas przemocą ze swobodnego obcowania i jawnego współdziałania z międzynarodową rodziną proletariacką - to główna zapora dla nas i zarazem nauka, że pierwszym naszym krokiem musi być zniesienie tego muru, gdyż tylko poza nim zaczyna się życie bardziej ludzkie"3. To bardziej cywilizowane życie istniało przede wszystkim w państwach zachodnich, które Piłsudski poznał podczas podróży w latach 1894-1899. Z ziem polskich jego uwagę zwróciła Galicja, która pod rządami cesarza Franciszka Józefa I była „najswobodniejszą częścią Polski" ${ }^{2}$. Piłsudski zdawał sobie w pełni sprawę z możliwości, jakie socjalistom z zaboru rosyjskiego dawała monarchia habsburska, mimo że zaborcza, do prowadzenia działań politycznych i rewolucyjnych. Konstytucyjny liberalizm panujący w Austro-Węgrzech oraz gwarancje dla emigrantów sprawiły, że Galicja stała się bazą operacyjną dla socjalistów

${ }^{1}$ J. Piłsudski, Pisma zbiorowe, t. 2, Warszawa 1937-1938, s. 52.

2 J. Holzer, PPS. Szkic dziejów, Warszawa 1977, s. 63; A. Ajnenkiel, Romana Dmowskiego i Józefa Piłsudskiego spór o Polskę, w: Do niepodległości 1918-1944/45-1989. Wizje, drogi, spetnienie, red. W. Wrzesiński, Warszawa 1998, s. 206; W. Jędrzejewicz, J. Cisek, Kalendarium życia Józefa Piłsudskiego 1867-1935, t. 1: 1867-1916, Kraków-Łomianki 2006, s. 53-84.

3 J. Piłsudski, Pisma zbiorowe, t. 1, Warszawa 1937-1938, s. 154.

${ }^{4}$ J. Piłsudski, Pisma zbiorowe, t. 8, Warszawa 1937-1938, s. 37; A. Garlicki, Józef Piłsudski 1867-1935, Kraków 2009, s. 118-119. 
z zaboru rosyjskiego, a w dalszej perspektywie przyczółkiem dla przygotowań wojskowych do walki z największym wrogiem - Rosją carską.

Pod koniec XIX w. Galicja stała się areną tak współpracy, jak i sporów różnych odłamów polskiego socjalizmu. Szczególne znaczenie miały kontakty Piłsudskiego i Polskiej Partii Socjalistycznej (PPS) z przedstawicielami Polskiej Partii Socjalno-Demokratycznej Galicji i Śląska (PPSD). Ważną instytucją Przedlitawii była Rada Państwa, a batalia socjalistów galicyjskich o wejście do parlamentu wiedeńskiego z V kurii głosowania powszechnego w marcu 1897 r. spotkała się z ogromnym zainteresowaniem i poparciem środowisk socjalistycznych w zaborze rosyjskim. Zaangażowany był w nią także Piłsudski, o czym świadczą licznie wzmianki w jego tekstach pisanych do „Przedświtu” i „Robotnika” oraz w korespondencji kierowanej w latach 1895-1900 do Centralizacji Związku Zagranicznego Socjalistów Polskich (ZZSP) $)^{5}$. W literaturze przedmiotu ten epizod $\mathrm{z}$ ostatnich lat XIX stulecia w życiu młodego Piłsudskiego został w różnym stopniu odnotowany przez biografów przyszłego Marszałka ${ }^{6}$. Nie ulega jednak wątpliwości, że był ważnym czynnikiem kształtującym jego poglądy społeczno-polityczne.

W centrum niniejszego artykułu znajdują się: stosunek Piłsudskiego do państw konstytucyjnych i współpracy z socjalistami z Galicji w latach 1892-1895, przygotowania do wyborów do V kurii Rady Państwa w Wiedniu w 1896-1897 r. oraz jego ocena działalności parlamentarnej posłów socjalistycznych IX kadencji 1897-1900, przy czym końcową cezurę stanowi aresztowanie Piłsudskiego przez władze carskie w nocy z 21 na 22 lutego 1900 r. w Łodzi.

Wobec państw konstytucyjnych i współpracy z socjalistami z zaboru austriackiego 1892-1895

Po powrocie z zesłania w 1892 r. 25-letni Piłsudski pogłębił swoje przekonania ideowe i zaangażował się w ruch socjalistyczny. Polska Partia

${ }^{5}$ J. Piłsudski, Pisma zbiorowe, t. 1, passim; Listy Józefa Piłsudskiego, oprac. W. Pobóg-Malinowski, L. Wasilewski, „Niepodległość” 13-20, 1935-1939. Oryginały listów są dostępne on-line na stronie Instytutu Józefa Piłsudskiego w Nowym Jorku.

${ }^{6}$ Galicyjski epizod z lat 1895-1900 w życiu Piłsudskiego najszerzej omówili: W. Pobóg-Malinowski, Józef Piłsudski 1867-1914, Łomianki 2015, s. 120, 142-143, 152-154 oraz W. Jędrzejewicz, J. Cisek, op. cit., s. 65-146. Nic nie piszą o stosunku Piłsudskiego do wyborów w Galicji w 1897 r.: W. Suleja, Józef Piłsudski, Wrocław 1995, passim; W. Jędrzejewicz, Józef Piłsudski. 1867-1935. Życiorys, Łomianki 2014; A. Garlicki, op. cit.; B. Urbankowski, Józef Piłsudski. Marzyciel i strateg, Warszawa 2014. 
Socjalistyczna, której zjazd założycielski odbył się w dniach 17-23 listopada 1892 r. w Paryżu, miała w swoim programie hasło ustanowienia demokratycznej republiki polskiej, opartej m.in. na bezpośrednim, tajnym i powszechnym głosowaniu i prawodawstwie ludowym, na równouprawnieniu narodowości wschodzących w skład Rzeczypospolitej na zasadzie dobrowolnej federacji, na równości wszystkich obywateli bez różnicy płci, rasy, narodowości i wyznania, na wolności słowa, druku, zebrań i stowarzyszeń7. Towarzysz „Wiktor”, wybrany w 1894 r. do pierwszego Centralnego Komitetu Robotniczego (CKR), zajął się wydawnictwem i dystrybucją materiałów propagandowych oraz nielegalnego pisma PPS - „Robotnika”. W wielu publikacjach wzywał robotników polskich do walki z caratem, uciskającym liczne narody, aby w ten sposób utrwalić swoją władzę. Piłsudski widział problem polski w szerszej perspektywie: braku jednolitości państwa rosyjskiego, skutków prowadzonej rusyfikacji i budzenia się niezadowolenia i świadomości nie tylko Polaków, ale także innych narodowości. Tradycja historycznej, samodzielnej egzystencji predestynowała je do odegrania głównej siły opozycyjnej i oznaczała, że mogą być czynnikami rozkładowymi imperium rosyjskiego ${ }^{9}$. Piłsudski wyciągnął stąd wniosek, że interesy proletariatu rosyjskiego zbiegają się z interesami polskimi, gdyż niepodległa Polska oznaczała śmierć caratu i wyzwolenie Rosji z tysiącletniej niewoli. W artykule Jak stałem się socjalista (1903) pisał bez ogródek: „Socjalista w Polsce dążyć musi do niepodległości kraju, a niepodległość jest znamiennym warunkiem zwycięstwa socjalizmu w Polsce"10. Patriotyzm był dostatecznie silną kotwicą dla Piłsudskiego, aby go utrzymać przy sprawie polskiej do końca życia. Od rewolucjonistów rosyjskich domagał się wsparcia politycznego programu PPS, czyli uznania prawa Polski do niepodległego bytu. Celem działalności socjalistów było dla niego ludowe powstanie, w wyniku którego odrodzi się niepodległa i demokratyczna Polska, umożliwiająca walkę o ustrój socjalistyczny ${ }^{11}$.

Piłsudski nie tkwił jednak bezwolnie poza „chińskim murem” carskiego despotyzmu. Odbywając w latach 1894-1899 podróże zagraniczne, zetknął się ze światem Europy Zachodniej ${ }^{12}$. Niewątpliwie miało to wpływ na jego poglądy polityczne. Dobrze zdawał sobie sprawę z korzyści życia

\footnotetext{
7 W. Pobóg-Malinowski, op. cit., s. 100.

8 Ibidem, s. 84-166.

9 Ibidem, s. 122-124; W. Suleja, op. cit., s. 29-32, 37-40.

${ }^{10}$ J. Piłsudski, Pisma zbiorowe, t. 2, s. 52-53; J. Gaul, Czarno-zółty miraż. Sprawa Józefa Piłsudskiego w monarchii habsburskiej 1896-1918, Warszawa 2018, s. 19-20.

11 A. Garlicki, op. cit., s. 85-89.

12 W. Pobóg-Malinowski, op. cit., s. 141-145; W. Jędrzejewicz, op. cit., s. 23-30.
} 
w systemie demokratycznym i konstytucyjnym dla sprawy robotniczej i walki politycznej. Wiedział o zmianie taktyki socjalistów zachodnioeuropejskich zapoczątkowanej w latach osiemdziesiątych i o przejściu od utopii wyczekiwanej powszechnej rewolucji do walki o zdobycze socjalne, o obecność robotników w parlamentach, o ubezpieczenia społeczne i prawa kobiet ${ }^{13}$. W odezwie na 1 maja 1895 r. pisał, że na całym Zachodzie towarzysze mogą wyrażać swoje niezadowolenie, stawiać żądania, zmuszać do ich wysłuchania, podczas gdy w zaborze rosyjskim każdy przejaw ruchu robotniczego jest surowo karany ${ }^{14}$. W sierpniu $1895 \mathrm{r}$. w artykule Nasze hasło, opublikowanym w „Robotniku”, dowodził, że w krajach demokratycznych „proletariat równą ze swymi przeciwnikami bronią walczy”" ${ }^{15}$. Na Zachodzie „wszędzie istnieją mniej lub bardziej szerokie konstytucje, które chociaż klasę robotniczą od udziału w rządach usuwają, zapewniają jednak wszystkim, w tej liczbie i robotnikom, pewną swobodę słowa, zebrań, organizacji, które ogromnie walkę ułatwiają"16. Te pozytywne dla robotników skutki ustroju konstytucyjnego, w którym rządzący, zależni od obywateli kraju, muszą przestrzegać obowiązujących praw, miały jednak swoją cenę, gdyż treść konstytucji uzależniona była od układu sił społecznych. Narzucała się zatem potrzeba pójścia o krok dalej i zdobycia demokratycznych urządzeń politycznych.

Doświadczenie historyczne uczy nas, że konstytucje demokratyczne, odpowiadające interesom klasy robotniczej, możliwymi są tylko tam, gdzie proletariat, dzięki potędze liczebnej i świadomości, poważną stanowi siłę i, korzystając z niej, na urządzenia politycznych [sic] piętno demokratyzmu wycisnąć potrafi. Tam zaś, gdzie proletariat do takiej powagi nie dorósł, klasy posiadające w ręce swe zagarniają władzę, i konstytucje, bladym, liberalnym atramentem pisane, masom pracującym niekiedy cień tylko swobody zostawiają ${ }^{17}$.

Dlatego po ewentualnym „zbankrutowaniu caratu” rosyjskie klasy panujące, korzystając z doświadczeń Zachodu, mogą przyjąć konstytucję, która będzie odpowiadać ich interesom, a nie robotników. Wspierając dążenia konstytucyjne w Rosji, stanowiące niewątpliwie krok naprzód, nie można zadowolić się ,połowiczną swobodą”:

${ }^{13}$ W. Pobóg-Malinowski, op. cit., s. 96-97; L. Kołakowski, Główne nurty marksizmu, t. 2, Warszawa 2009, s. 9-19.

${ }^{14}$ J. Piłsudski, Pisma zbiorowe, t. 1, s. 76-77; W. Jędrzejewicz, J. Cisek, op. cit., s. 64-65.

15 J. Piłsudski, Pisma zbiorowe, t. 1, s. 101.

16 Ibidem.

17 Ibidem, s. 102; W. Pobóg-Malinowski, op. cit., s. 121. 
W walce więc o prawa polityczne hasłem polityki robotniczej, odpowiadającej jej potrzebom i ze ścisłej analizy stosunków społecznych Rosji i Polski wynikającym, może być tylko Niepodległa Rzeczpospolita Polska, która dzięki wpływowi proletariatu inną, jak demokratyczną, być nie może; w ramach jej proletariat polski potrafi zapewnić sobie szerokie swobody polityczne i odpowiednio do swej siły i świadomości udział w prawodawstwie i rządzie. Niepodległość Polski, dając proletariatowi demokratyczny ustrój, usunie zarazem tamy i zapory, jakie zwykle rozwojowi cywilizacyjnemu podbitego narodu stawią rządy zaborcze ${ }^{18}$.

Do zwycięstwa socjalizmu potrzebne było także połączenie wysiłków socjalistów polskich. Piłsudskiemu i kierowanej przez niego PPS chodziło o prowadzenie działalności na gruncie ogólnopolskim, aby w pracy i stawianych celach zniknął podział kraju na trzy zabory. Przekonanie to znalazło wyraz już na kongresie w Brukseli w 1891 r. i powołaniu w roku następnym w Paryżu Związku Zagranicznego Socjalistów Polskich ${ }^{19}$. Na trzecim Zjeździe PPS 29 czerwca 1895 r. w Wilnie uznano wspólnotę kulturalną i historyczną oraz wspólne interesy polskiej klasy robotniczej, pomimo różnych warunków polityczno-państwowych w trzech państwach zaborczych. Zobowiązano Centralny Komitet Robotniczy, aby dążył do bliższego porozumienia z bratnimi organizacjami socjalistycznymi. Szczególnego znaczenia nabierało ustalenie relacji i pogłębienie współpracy z polskim ruchem socjalistycznym w Galicji, m.in. z powodu przekształceń ustrojowych w monarchii habsburskiej ${ }^{20}$.

W skład imperium habsburskiego wchodziły liczne kraje i narody, w tym także Polacy, którzy stali się poddanymi austriackiego cesarza w wyniku rozbiorów. W latach sześćdziesiątych XIX w. doszło w monarchii do ostatecznego zerwania z neoabsolutyzmem i przyjęcia konstytucji w grudniu 1867 r. Austro-Węgry w okresie konstytucyjnym (1867-1914) przekształciły się $\mathrm{w}$ państwo prawa, zapewniające swoim obywatelom podstawowe przywileje i wolności polityczne ${ }^{21}$. Konstytucjonalizm

${ }^{18}$ J. Piłsudski, Pisma zbiorowe, t. 1, s. 105-106; W. Jędrzejewicz, J. Cisek, op. cit., s. 6970; W. Jędrzejewicz, op. cit., s. 23-24; W. Pobóg-Malinowski, op. cit., s. 121-122.

19 W. Pobóg-Malinowski, op. cit., s. 99-100.

20 Listy Józefa Piłsudskiego, „Niepodległość” 13, 1936, s. 150-151; W. Pobóg-Malinowski, op. cit., s. 100-104, 152.

${ }^{21}$ Zdaniem Andrzeja Dziadzia, w monarchii konstytucyjnej w Austrii (1867-1914) doszło do połączenia monarchicznego czynnika rządzącego z systemem liberalno-konstytucyjnego porządku prawnego. „Austriacka monarchia konstytucyjna stała się pierwowzorem współczesnego państwa prawnego, stworzyła bowiem liczne instytucje ochrony prawnej obywateli przed arbitralnością poczynań władz". Opracowano wówczas sposób zabezpieczenia praw wolności obywatelskich w postaci niezależnego, 
przyniósł autonomię krajom, w tym także Galicji i Śląskowi Cieszyńskiemu, reprezentowanym w Radzie Państwa. Galicja ze swoimi polskimi szkołami, z wpływem na sprawy państwowe i politykę austriacką była dla wielu Polaków tym, czym na początku stulecia było Księstwo Warszawskie - ogniskiem wielkich nadziei i zapowiedzią ich urzeczywistnienia, stanowiąc centrum polskości i oazę wolności w porównaniu z innymi zaborami ${ }^{22}$. Nie oznaczało to jednak automatycznego przyznania równych praw politycznych. Władza w monarchii habsburskiej pozostawała w rękach uprzywilejowanej grupy, wywodzącej się z warstw posiadających.

Pod koniec XIX w. konserwatywne ugrupowania w państwie austro-węgierskim zostały skonfrontowane z masowymi ruchami politycznymi warstw niższych. Jednym z nich był socjalizm, który objął w tym czasie liczne kraje europejskie. W monarchii habsburskiej do założenia partii socjalistycznej doszło na kongresie w Hainfeld (Dolna Austria) w dniach 30 grudnia $1888-1$ stycznia $1889 \mathrm{r} .{ }^{23}$ Programowi Socjaldemokratycznej Partii Austrii, stworzonemu przez Viktora Adlera, przyświecało hasło:

specjalnego sądu o charakterze konstytucyjnym. „Działalność Trybunału Państwa i Trybunału Administracyjnego przyczyniła się do tego, że aparat państwowy został zmuszony do przestrzegania konstytucyjnego porządku prawego". Wadą konstytucji grudniowej z 1867 r. była centralistyczna struktura państwa i brak właściwego rozwiązania kwestii narodowościowych, co spowodowało, że stabilizacja państwa zależała od utrzymania mocnej pozycji władzy cesarskiej. „System ustrojowy monarchii austriackiej nie rozwinął się więc w kierunku rządów parlamentarnych, lecz przyniósł nawrót do monarszego autorytaryzmu, gdyż w końcowym okresie porządek prawny opierał się coraz bardziej na specjalnych rozporządzeniach cesarskich". Pojawienie się w Austrii pod koniec XIX w. nacjonalizmu i antysemityzmu przyczyniało się do stopniowej utraty przez monarchię charakteru uniwersalistycznego państwa. Austriackie trybunały państwowe zwalczały jednak ruchy nacjonalistyczne i antysemickie, dostrzegając w tym przejawy nadużywania wolności konstytucyjnych. Kryzys liberalnego porządku prawnego w schyłkowym okresie istnienia austriackiej monarchii konstytucyjnej przyniósł wzmocnienie struktur rządowych, działających w duchu klerykalnym i zachowawczym. Niezależne trybunały tworzyły jednak swym orzecznictwem tamę wobec takich postaw administracji, narzucających wyznaniowy charakter państwa, A. Dziadzio, Monarchia konstytucyjna w Austrii (1867-1914). Władza - obywatel - prawo, Kraków 2001, s. 289-290.

22 S. Grodziski, W Królestwie Galicji i Lodomerii, Kraków 1976, s. 226-229; idem, Franciszek Józef I, Wrocław-Warszawa-Kraków 1978, s. 119-120; idem, Sejm Krajowy Galicyjski 1861-1914, t. 2, Warszawa 1993, s. 254-257; H. Wereszycki, Historia Austrii, Wrocław-Warszawa-Kraków 1986, s. 232-233; S. Pijaj, Między polskim patriotyzmem a habsburskim lojalizmem. Polacy wobec przemian ustrojowych monarchii habsburskiej (1866-1871), Kraków 2003, s. 329-330; D. Litwin-Lewandowska, O polska rację stanu w Austrii. Polacy w życiu politycznym Austrii w okresie monarchii dualistycznej (1867-1918), Lublin 2008, s. 349-404.

23 Socjalistów galicyjskich reprezentował zecer ze Lwowa Naftali Telz, zob. W. Najdus, Polska Partia Socjalno-Demokratyczna Galicji i Ślaska 1890-1919, Warszawa 1983, s. 93-94. 
„Nie ma demokracji bez wolności, nie ma socjalizmu bez demokracji”24. Ugrupowanie akceptowało istnienie państwa austriackiego, a walka proletariatu o bezklasowe społeczeństwo miała się odbywać nie na rewolucyjnej, lecz na ewolucyjnej drodze, chociaż parlamentaryzm został oceniony jako forma panowania klasowego ${ }^{25}$. Upowszechnianie się myśli socjalistycznej objęło także obszary polskie przyłączone do Austrii w wyniku zaborów. W Galicji, gdzie istniały tylko niewielkie skupiska robotnicze, agitacja socjalistyczna szerzyła się początkowo w kółkach młodzieży rzemieślniczej i studenckiej, m.in. w wyniku działalności pioniera socjalizmu polskiego, Bolesława Limanowskiego ${ }^{26}$. Austriacka partia socjalistyczna obejmowała całą monarchię, a więc także Galicję i śląsk Cieszyński, i we Lwowie oraz w Krakowie powstały jej miejscowe zarządy. 31 stycznia 1892 r. delegaci z dziewięciu miast galicyjskich powołali do życia Galicyjską Partię Socjalno-Demokratyczną (GPS). Partia przyjęła oparty na zasadach marksistowskich program uchwalony w Hainfeld, lecz widziała też potrzebę walki o przyszłość robotniczej Polski ${ }^{27}$.

Od samego początku Galicyjska Partia Socjalno-Demokratyczna była uwikłana w problematykę narodową - musiała określić swoje miejsce w społeczeństwie polskim, swój stosunek do państw zaborczych oraz do polskich ugrupowań socjalistycznych na pozostałych ziemiach zabranych i na emigracji: PPS i Socjaldemokracji Królestwa Polskiego i Litwy (SDKPiL). Ignacy Daszyński w Wiedniu w 1892 r. na kongresie austriackiej socjaldemokracji oświadczył w imieniu polskich delegatów, iż pomimo obustronnych życzeń, nie mogą tak ściśle związać się z organizacją

24 „Keine Demokratie ohne Freiheit, kein Sozialismus ohne Demokratie”.

${ }^{25}$ L. Brügel, Geschichte der österreichischen Sozialdemokratie, t. 4, Wien 1923, s. $162-$ 163; H. Konrad, Nationalismus und Internationalismus. Die österreichische Arbeiterbewegung vor dem Ersten Weltkrieg, Vienna 1976, s. 47-48; F. Kaufmann, Sozialdemokratie in Österreich. Idee und Geschichte einer Partei von 1889 bis zur Gegenwart, Wien-München 1978, s. 29-30; W. Najdus, Polska Partia Socjalno-Demokratyczna, s. 91-94; R.G. Ardelt, Sozialdemokratie und Bürgerliche Öffentlichkeit. Überlegungen zum Hainfelder Parteitag, w: Politik und Gesellschaft im alten und neuen Österreich. Festschrift für Rudolf Neck zum 60. Geburtstag, t. 1, red. I. Ackerl, W. Hummelberger, H. Mommsen, Wien 1981, s. 214-238; idem, Vom Kampf um Bürgerrechte zum „Burgfrieden”. Studien zur Geschichte der österreichischen Sozialdemokratie 1888-1914, Wien 1994, s. 9-29; H. Kuprian, An der Schwelle zum 20. JahrhundertStaat und Gesellschaft vor dem Erstem Weltkrieg, w: Österreich im 20. Jahrhundert, t. 1: Von der Monarchie bis zum Zweiten Weltkrieg, red. R. Steininger, M. Gehler, Wien-Köln-Weimar 1997, s. 23-24.

${ }^{26}$ W. Najdus, Polska Partia Socjalno-Demokratyczna, s. 39-88; L. Brügel, op. cit., s. 139.

${ }^{27}$ J. Holzer, op. cit., s. 62-63; W. Najdus, Polska Partia Socjalno-Demokratyczna, s. 102111; Von der Donaumonarchie zum vereinten Europa. 20 Reichsratsabgeordnete die Geschichte schrieben, red. A.P. Pittler, M.-L. Janota, Klagenfurt-Wien-Ljubjana-Sarajevo 2003, s. 239. 
austriacką jak inne narodowości wobec położenia kraju, „którego granice polityczne nie odpowiadają stosunkom faktycznym i językowym" oraz „ze względu na rodaków, żyjących poza granicami państwa i oczekujących pomocy od socjalistów polskich w Galicji"28.

Dla polskich sympatyków idei socjalistycznej z zaboru rosyjskiego, łączących ją z formułą niepodległościową, zastrzeżenia budził brak określenia „polska” w nazwie partii galicyjskiej i zbytnia jej zależność od austriackiej partii socjalno-demokratycznej. Dla Leona Wasilewskiego w 1893 r. stanowisko tej partii „było zbyt prowincjonalne, nie widziałem w niej - poza uroczystymi wystąpieniami - konkretnych dążności do połączenia ruchu socjalistycznego we wszystkich trzech zaborach, co było programem Związku Zagranicznego Socjalistów Polskich i jego organu londyńskiego "Przedświtu»" ${ }^{29}$. W sierpniu 1893 r. na międzynarodowym kongresie socjalistycznym w Zurychu polska delegacja trzech zaborów starła się z przedstawicielami Socjaldemokracji Królestwa Polskiego - Różą Luksemburg, Julianem Marchlewskim i Adolfem Warskim, którzy stali na gruncie organicznego wcielenia ziem polskich do państw zaborczych i uznawali dążenia niepodległościowe w obozie socjalistycznym za czynnik podstępnie narzucony robotnikom przez inteligentów. Stanowisko SDKPiL uważane było przez wielu, także przez Daszyńskiego, za zgubne dla polskiego ruchu socjalistycznego. Dystans do SDKPiL nie oznaczał jednak dla socjalistów z Galicji automatycznego utożsamienia się z programem PPS z zaboru rosyjskiego, mimo coraz intensywniejszych wzajemnych kontaktów ${ }^{30}$.

W pismach Piłsudskiego od 1894 r. pojawiają się informacje o Galicji, świadczące o jego zainteresowaniu zaborem austriackim i o coraz bardziej ożywionych kontaktach ${ }^{31}$. Na przykład 29 kwietnia 1894 r. proponował ZZSP skontaktowanie się z pismem „Arbeiter”32, wydawanym od $1893 \mathrm{r}$. w Galicji przez Galicyjską Partię Socjalno-Demokratyczną ${ }^{33} .5$ czerwca 1895 r. pytał się ZZSP o listy z pozdrowieniami od organizacji

${ }^{28}$ I. Daszyński, Pamiętniki, t. 1, Kraków 1925, s. 79-80; L. Wasilewski, Zarys dziejów Polskiej Partii Socjalistycznej. W zwiazku z historia socjalizmu polskiego w trzech zaborach i na emigracji, Warszawa 1924, s. 31-32.

29 A. Próchnik, Leon Wasilewski w polskim ruchu socjalistycznym, „Niepodległość” 16, 1937, s. 118.

30 Listy Józefa Piłsudskiego, „Niepodległość” 13, 1936, s. 460, 469; W. Pobóg-Malinowski, op. cit., s. 101-102.

${ }^{31}$ J. Gaul, Czarno-żólty miraż, s. 23.

32 „Arbeiter” - pismo agitacyjne dla robotników żydowskich, założone w 1893 r. we Lwowie przez Galicyjską Partię Socjalno-Demokratyczną.

33 Listy Józefa Piłsudskiego, „Niepodległość” 12, 1935, s. 150; W. Jędrzejewicz, J. Cisek, op. cit., s. 56. 
socjalistycznych z zaborów austriackiego i pruskiego na III zjazd PPS, który odbył się w 29 czerwca 1895 r. w Wilnie, a także o sprawy wydawnicze w Galicji ${ }^{34}$. W liście z 23 grudnia 1895 do ZZSP interesowały go obchody w Galicji rocznicy stracenia w 1886 r. czterech członków Proletariatu ${ }^{35} .23$ marca 1896 r. informował Witolda Jodko-Narkiewicza w Bernie, że w planowanej broszurze Pamiatka Majowa wydanej w Londynie w 1896 r. pojawią się artykuły socjalistów z zaboru austriackiego Daszyńskiego i Róży Altenberg (ps. Helena Rawska) ${ }^{36} .24$ marca 1896 r. w liście do CKR PPS towarzysz „Wiktor” cieszył się, że Daszyński będzie wpływać na socjalistów austriackich w sprawie poparcia przygotowywanego na IV kongres londyński wniosku PPS w sprawie uznania hasła niepodległości Polski za postulat II Międzynarodówki ${ }^{37}$.

Piłsudski, zaangażowany w nielegalną działalność w Kongresówce, początkowo widział przeszkody w zbliżeniu socjalistów z zaboru rosyjskiego do „Galicjan”. W liście z 13 maja 1896 r. do CKR opisywał je tak: „Co do mnie, to po namyśle i poradzeniu się zarówno rozumu, jak uczuć, nie chciałbym tego dla następujących przyczyn. Wątpię, by ta gawęda doprowadziła do pożądanych rezultatów, wobec tego, że główny ich facet D.[aszyński] bardzo jest niechętny wszelkim konspiracjom"38. Przekroczenie bariery legalnego działania było dla Piłsudskiego bardzo trudne do pokonania, gdyż na ziemiach zaboru rosyjskiego bez przestrzegania zasad surowej konspiracji jakakolwiek działalność socjalistów była niemożliwa ${ }^{39}$. Miesiąc później zrewidował częściowo swoje negatywne stanowisko. 9 czerwca 1896 r. docenił fakt, że „Dasz.[yński] ostatnio przysłał nam list [z 1 VI 1896] bardzo serdeczny i zachęcający do wspólnej polityki" ${ }^{40}$. Ta współpraca była możliwa, ale po spełnieniu pewnych warunków. „Sądzę, że ustanowić należy a) każdy z zaborów nie będzie zawierał stosunków poza plecami innego zaboru [--], dalej wspólny pogląd na kwestię rusińską i oddziaływanie przez Galicjan na naszych Rusinów w pożądanym kierunku"41. W sprawie zaznajomienia zaborów ze sobą,

${ }^{34}$ J. Piłsudski, Pisma zbiorowe. Uzupetnienia, t. 1: 1886-1897, red. A. Garlicki, R. Świętek, Warszawa 1992, s. 116.

${ }^{35}$ J. Piłsudski, Pisma zbiorowe, t. 1, s. 161-162; idem, Pisma zbiorowe. Uzupetnienia, t. 1 , s. 136.

${ }^{36}$ J. Piłsudski, Pisma zbiorowe. Uzupełnienia, t. 1, s. 140; idem, Pisma zbiorowe, t. 1, s. 146-147; W. Pobóg-Malinowski, op. cit., s. 136.

37 J. Piłsudski, Pisma zbiorowe. Uzupetnienia, t. 1, s. 145.

${ }^{38}$ Listy Józefa Piłsudskiego, „Niepodległość” 15, 1937, s. 120.

39 W. Pobóg-Malinowski, op. cit., s. 107-111.

40 Listy Józefa Piłsudskiego, „Niepodległość” 15, 1937, s. 426.

${ }^{41}$ Ibidem, s. 426-427. 
„to doprawdy nasze narzekanie na Galicjan za zbytnią galicyjskość ich pism nie ma wiele racji, gdyż faceci powiadają, że zadawalniać się przedrukami nie mogą, a muszą mieć wiadomości z pierwszej ręki, tj. trzeba by było dlatego ustanowić korespondencję do nich i zażądać od nich w zamian korespondencję do nas" 42 .

Przygotowania do wyborów do V kurii Izby Posłów w Wiedniu 1896-1897

Zgodnie z ustawą zasadniczą o reprezentacji państwa, ogłoszoną wraz z patentem lutowym, Galicja w latach 1861-1873 delegowała 38 deputowanych wybieranych z grona posłów sejmowych. Na mocy ustawy wyborczej z 2 kwietnia 1873 r. Galicji przyznano 63 mandaty. Posłowie byli wybierani w ramach czterech kurii - wielkiej własności ziemskiej, miast, izb handlowych i przemysłowych, gmin wiejskich ${ }^{43}$. Socjaliści nie byli reprezentowani w Izbie Posłów Rady Państwa w Wiedniu, gdyż cztery kategorie skupiające wyborców zależnie od ich pozycji społecznej i stanu majątkowego wykluczały uzyskanie przez działaczy reprezentacji parlamentarnej. Sprzeczności między strukturą społeczeństwa a jego reprezentacją parlamentarną były tak głębokie, że Daszyński nazwał Galicję „folwarkiem wydzierżawionym szlachcie”"44.

Reformy wyborcze przeprowadzone pod koniec XIX w. pozwoliły zaistnieć na forum parlamentu wiedeńskiego partiom masowym, w tym socjalistom z Galicji i Śląska. 5 maja 1896 r. prezes Rady Ministrów Kazimierz Badeni, mając poparcie konserwatystów austriackich oraz Czechów, zjednanych koncesjami językowymi, dodał V kurię powszechnego głosowania dla ludności nieposiadającej. Uprawnienia wyborcze uzyskali mężczyźni od 24 roku życia, nie, jak dawniej, płacący podatki, lecz przebywający przynajmniej przez sześć miesięcy w gminie austriackiej. Podczas gdy do roku 1896 liczba wyborców sięgała około 1,7 mln, po reformie wzrosła do 5,3 mln. 72 mandaty V kurii, które dołączyły do dotychczasowych 353, zwiększyły do 425 liczbę posłów w Izbie Posłów Rady Państwa.

42 Ibidem, s. 427.

43 Protokoły Koła Polskiego w wiedeńskiej Radzie Państwa (lata 1867-1868), oprac. i wstęp Z. Fras, S. Pijaj, Kraków 2001, s. 184-188: Załącznik nr 3: „Program polski”; J. Zdrada, Organizacja i stanowisko Koła Polskiego w wiedeńskiej Radzie Państwa (1861-1862), „Zeszyty Naukowe Uniwersytetu Jagiellońskiego. Prace Historyczne" 1963, 12, s. 62-76; S. Pijaj, op. cit., s. 162-164.

44 Cyt. za: P. Wandycz, Pod zaborami 1795-1918, Warszawa 1994, s. 385. 
W przypadku Galicji oznaczało to dodanie piętnastu nowych mandatów do istniejących już sześćdziesięciu trzech ${ }^{45}$.

Batalia socjalistów galicyjskich o wejście do parlamentu wiedeńskiego siedmiu zgłoszonych kandydatów ${ }^{46}$ spotkała się z ogromnym zainteresowaniem i poparciem środowisk socjalistycznych w zaborze rosyjskim. Piłsudski był dobrze zorientowany w wydarzeniach politycznych w Austrii i oczekiwał nie tylko wyboru w Galicji przynajmniej dwóch socjalistów, lecz widział także potrzebę aktywnego ich wsparcia. Jak pisał 25 czerwca 1896 r. do CKR:

zbliżają się w Galicji wybory z piątej kurii. Sądzimy, że zapewne 2 przejdzie naszych (z Krakowa i Lwowa) ${ }^{47}$, czy nie wartałoby [sic] dla zamanifestowania łączności posłać im na fundusz wyborczy trochę pieniędzy i stosowne listy, co o tym sądzicie? Sądzę też, że na obradach 3 zaborowych będzie gadanie o przyszłych naszych posłach w Wiedniu. Sprawa ta ma całkiem realne dla nas znaczenie, gdyż przez nich będziemy mogli robić tam awantury z powodu naszych spraw. Co o tym myślicie, czy mam przy naradach mówić z nimi o czymkolwiek w tym guście ${ }^{48}$.

Tworzenie wspólnej reprezentacji przedstawicieli polskiego ruchu socjalistycznego z trzech zaborów na IV kongres socjalistyczny w Londynie szło opornie, zwłaszcza z powodu słabej reprezentacji Galicji. Jak pisał 6 lipca 1896 r. do CKR zirytowany Piłsudski,

z Galicji prawdopodobnie będzie jeden tylko Daszyński [w rzeczywistości był także Jan Kozakiewicz - J.G.]. Idioty galicyjskie teraz strajkują na łeb wszyscy i wszędzie i nie mają grosza na posłanie delegatów. A wobec podziału Galicji na dwa zarządy [w Krakowie i w Lwowie] i pewnej niechęci pomiędzy jednymi a drugimi, narada do żadnych rezultatów zapewne nie doprowadzi, tym bardziej że dla nas ważniejszym jest może Lwów, jak Kraków. Nasi tutaj

${ }^{45}$ L. Brügel, op. cit., s. 294-297, 305-312; P. Wandycz, op. cit., s. 385-386; W. Łazuga, „Rzady polskie” w Austrii. Gabinet Kazimierza hr. Badeniego 1895-1897, Poznań 1991, s. 127-144; G. Schefbeck, Parlament wielonarodowy, w: Viribus Unitis? Polscy parlamentarzyści w monarchii habsburskiej 1848-1918, red. B. Górska, Kraków 2012, s. 43; J. Gaul, Między Austria a Polska. Posłowie galicyjscy w parlamencie wiedeńskim, w: Viribus Unitis?, s. 63-64.

${ }^{46}$ Socjaliści wystawili swoich kandydatów w siedmiu okręgach: Lwów - Jan Kozakiewicz, Kraków - Ignacy Daszyński, Wadowice - Jan Englisch, Nowy Sącz - Leon Misiołek, Tarnów - Franciszek Sułczewski, Rzeszów i Jarosław - Kornel Żelaszkiewicz, Stanisławów - Julian Obirek, zob. W. Najdus, Polska Partia Socjalno-Demokratyczna, s. 193.

${ }^{47}$ Piłsudski trafnie ocenił szanse Daszyńskiego i Kozakiewicza, zob. W. Najdus, Ignacy Daszyński 1866-1936, Warszawa 1988, s. 114-124.

${ }^{48}$ Listy Józefa Piłsudskiego, „Niepodległość” 16, 1937, s. 504; J. Gaul, Czarno-żótty miraż, s. 23-24. 
mają jeszcze w tym względzie pewne nadzieje, że i tak to będzie coś, ale co do mnie, uważam za chybione nasze zamiary.

I dalej karcił Galicjan za zbyt małe zaangażowanie we wspólne konferencje: „Jak się zdaje, Galicja głównie by nastawała na pomoc pieniężną w wyborach - o tym już pisali ze Lwowa"49. Piłsudski w lipcu 1896 r., m.in. także z Daszyńskim, wziął udział w IV Kongresie II Międzynarodówki Socjalistycznej w Londynie, na którym przyjęto, chociaż w zmienionej formie, polski wniosek w sprawie niepodległości Polski ${ }^{50}$. Podczas spotkań wewnętrznych delegacji polskiej rozmawiano o wyborach do parlamentu austriackiego i socjalistycznych kandydatach. W rezultacie przygotowano odezwę, w której stwierdzono, że Polska, mimo dokonanych rozbiorów, jest w sercach robotniczych „jedną i niepodzielną" i wezwano do energicznego zbierania składek „na fundusz wyborczy partii socjalistycznej w Galicji" 51 .

W sprawie „polityki wspólnej” zarysowały się istotne różnice. Piłsudski uważał, jak wynika z jego listu z 6 lipca 1896 r. do CKR, że socjaliści galicyjscy chcieli ją prowadzić na gruncie austriackim „i politykę wspólną uważają jedynie zapewne [?] w parlamencie wiedeńskim, co dla nas znowu ma nie tak wielkie znaczenie" 52 . Zagadnienie to gnębiło go i 15 lipca 1896 r. powrócił do tematu w liście do Aleksandra Sulkiewicza. Jego zdaniem, nawiązanie ściślejszych kontaktów z Galicją w celu prowadzenia „wspólnej polityki w Wiedniu” nie było łatwe do realizacji, gdyż w środowisku socjalistów galicyjskich narastały nastroje „wiedeńsko-centralistyczne", mniej interesowano się Polską niż Wiedniem i zbyt mocno wiązano pracę z ruchem ogólnoaustriackim ${ }^{53}$. Piłsudski widział współpracę w szerszym, ogólnopolskim wymiarze, a wspólna polityka w Wiedniu była tylko jednym z jej elementów. We wspomnianym liście zastanawiał się nad możliwościami, jakie powstaną po wyborze posłów socjalistycznych do parlamentu wiedeńskiego. Uważał, że "galileusze” „fundują głównie tę wspólną politykę" na swojej obecności w parlamencie austriackim w Wiedniu. Natomiast sam pozostawał na gruncie wysuniętej w czerwcu formuły „awantury z powodu naszych spraw”:

49 Listy Józefa Piłsudskiego, „Niepodległość” 17, 1938, s. 40.

50 J. Piłsudski, Pisma zbiorowe, t. 1, s. 147-150 (chodzi o artykuł Z Kongresu zamieszczony w „Robotniku” nr 17 z 4 X 1896); W. Pobóg-Malinowski, op. cit., s. 141-143; W. Jędrzejewicz, op. cit., s. 26-27.

${ }^{51}$ Listy Józefa Piłsudskiego, „Niepodległość” 16, 1937, s. 504, przyp. 39; W. Pobóg-Malinowski, op. cit., s. 142-143, 152-153.

52 Listy Józefa Piłsudskiego, „Niepodległość” 17, 1938, s. 40.

${ }^{53}$ Ibidem, s. 50-51. 
Co do mnie, to na razie nie wyobrażam nic innego, jak że od czasu do czasu przy zdarzonej sposobności da się zrobić awantura, zbesztać rząd rosyjski et caet. Może wy macie jakieś realniejsze wnioski w tym względzie? W każdym razie, gdybyśmy się zobowiązali i co do korespondencji i polityki wspólnej w Wiedniu, musielibyśmy nawiązać ściślejsze stosunki z Galileą, chociażby przez urządzenie poczty stałej do nich bezpośrednio, a nie przez Londyn ${ }^{54}$.

4 sierpnia 1896 r. Piłsudski powrócił w liście do CKR do sprawy wyborów w Galicji:

Składki na wybory w Galicji trzeba teraz rozpisać, wydać w numerze krótką odezwę i listy na składki - wybory zapewne będą albo za parę miesięcy, albo na wiosnę, trzeba się więc w pierwszym wypadku spieszyć. Wystawia ono, zdaje się, 4 kandydatów (chociaż to jeszcze nie na pewno i kandydaci nie są postawieni) w Krakowie, we Lwowie, Przemyślu i Stanisławowie ${ }^{55}$, liczą, że przejdzie najwyżej 2, albo nawet $1 \mathrm{w}$ Krakowie, no i potrzebują, rozumie się, moc pieniędzy na agitację ${ }^{56}$.

Sprawa finansowego wsparcia utknęła jednak w miejscu. Odżyła dopiero pod koniec roku, zapewne w związku z ogłoszeniem decyzji o przeprowadzeniu wyborów w marcu 1897 r.

Dłuższy pobyt Piłsudskiego w Krakowie i we Lwowie w sierpniu i wrześniu 1896 r. pozwolił zweryfikować sytuację w zaborze austriackim. W liście z 15 września 1896 r. do ZZSP wyłożył jasno swoje wnioski i zastrzeżenia wobec roli Galicji:

Dla nas bez wątpienia Galicja bardzo wielkie ma znacznie i może stać się podstawą dla wielu operacji, ale trzeba mieć tu swoich ludzi. Z tutejszymi [z socjalistami polskimi z PPSD - J.G.] wątpię, by się udało prędko cokolwiek nawiązać. Oni chętnie przyjmą wszelką pomoc, ale okazać jej innym, albo nie zechcą, albo też nie potrafią. Takie jest moje wrażenie ze wszystkich rozmów, jakie z nimi miałem, i dopiero po stosownym na nich oddziaływaniu może się coś nie coś w nich zmienić.

Najważniejszą przeszkodą dla Piłsudskiego była legalność działań socjaldemokracji galicyjskiej.

Najprzód jest tu kierunek powszechny legalności, która jakoby ma być szczytem mądrości politycznej, a stąd brak zupełny wśród ludzi konspiracyjności

54 Ibidem, s. 51

55 Ostatecznie PPSD wystawiła siedmiu kandydatów, zob. przyp. 46.

${ }^{56}$ Listy Józefa Piłsudskiego, „Niepodległość” 17, 1938, s. 62. 
jakiej takiej. W tym względzie dobrze byłoby w „Przedświcie” ${ }^{57}$ parę rzeczy zamieścić, zbijające [sic!] wiarę w cudowność legalności; byłoby to tym bardziej na czasie, że jeszcze wszelkie niedobitki organizacyjne i umysłowe byłego „Związku” [Związek Robotników Polskich - J.G.] chorują i u nas na wielkich mądrali od legalności ruchu. Jeżeli by można było przytoczyć jako przykład Niemców i opisać ich konspirację, byłoby [sic!] to dla ludzi bardzo przekonywujący przykład, albowiem sławetna legalność w umysłach tych ludzi wiąże się zawsze z Niemcami, którzy jakoby mają być pur sang legaliści ${ }^{58}$.

Kolejną przeszkodą we wzajemnej współpracy był całkowity brak orientacji socjalistów galicyjskich w stosunkach w Królestwie Polskim. „Rozumie się, część winy spada tu na nas samych, ale jest wina i ich menerów, którzy przecie powinni znać literaturę naszą i rozumieć nasze położenie chociażby w ogólnych zarysach”. Domagał się solidarności także w traktowaniu spraw rosyjskich: „powinni przedstawiać rzeczy tak, jak my je przedstawiamy (mowa była o Rosji) i we wszystkich sprawach, tyczący się Rosji, trzymać się ściśle naszych wskazówek, a nie iść ślepo za informacjami w «Vorwärtsie» i «Arbeiter Zeitung»". I dalej:

Ale, zdaje się, moje słowa - to groch o ścianę. Tu trzeba systematycznego wpływu i w pierwszym rzędzie ta robota musi być robota „Przedświtu”, ale na to trzeba, żeby on wychodził regularnie i prędko dochodził tutaj po wyjściu. Wiem dobrze, że to nie łatwe jest zadanie, ale konieczne. Praktyczne zaś sprawy, jakie będziemy mieli do załatwienia, trzeba będzie przeprowadzać siłami własnymi, - będzie to i bezpieczniej, i porządniej. A na naszych tutaj ciągle wpływać, by mniej byli Galicjanami, a więcej Polakami ${ }^{59}$.

Istotną przeszkodą była też negatywna ocena działalności Daszyńskiego. Na początku 1897 r. Aleksander Dębski pisał: „Ignaś zachowuje się pod psem... Ze swego partykularyzmu już nie galicyjskiego, ale po prostu krakowskiego jeszcze się nie wyleczył. Dla niego w Polsce istnieje Galicja, w Galicji tylko Kraków, w Krakowie - on"60. Piłsudski twierdził 12 lutego 1897 r. w liście do ZZSP, „że Ignaś różne bzdurstwa gada,

57 „Przedświt” był od 1881 r. organem emigracyjnym polskiego ruchu socjalistycznego. W 1893 stał się pismem ZSP, a od stycznia 1900 został przekształcony w organ PPS. Wychodził początkowo w Genewie, potem w Londynie, od 1903 w Krakowie.

58 Listy Józefa Piłsudskiego, „Niepodległość” 17, 1938, s. 210; J. Buszko, Józef Piłsudski w Krakowie 1896-1935, Kraków 1990, s. 5.

59 Listy Józefa Piłsudskiego, „Niepodległość” 17, 1938, s. 210-211; W. Pobóg-Malinowski, op. cit., s. 153-154.

${ }^{60}$ Listy Józefa Piłsudskiego, „Niepodległość” 18, 1938, s. 205. 
temu się wcale nie dziwię. Facet zbyt wiele ma drobnostkowej ambicji i miłości własnej"61.

Do bliższej współpracy Królewiaków z Galicjanami potrzebne było przezwyciężenie nie tylko animozji osobistych, ale także zrozumienie zasadniczej różnicy między despotycznym systemem carskim, a konstytucyjną monarchią habsburską, która z wolna zmierzała, podobnie jak niemiecka Rzesza pomimo antypolskiej polityki, do modelu zachodniego. Piłsudski rozumiał, że droga, po której kroczą robotnicy w państwach zachodnich, korzystający ze swobód politycznych w walce $\mathrm{z}$ ustrojem kapitalistycznym, jest zamknięta dla proletariatu w zaborze rosyjskim z powodu istnienia "samowładnego rządu carskiego". Jak pisał 4 października 1896 r. w „Robotniku”: „nie możemy, jak oni, żądać wprowadzenia albo zniesienia tych lub owych praw, gdyż nie tylko nie mamy żadnego udziału w prawodawstwie, ale nawet zabronione nam jest publiczne wyjawianie swych chęci i potrzeb. Nie możemy też wspólnie z nimi stanąć do walki, zorganizowani w wielkie związki zawodowe, gdyż znowu na przeszkodzie nam stoi rząd carski ze swymi prawami barbarzyńskimi, sforą żandarmów i szpiegów"62. Piłsudski zaczął powoli dostrzegać jakościową różnicę życia w zaborze austriackim i niemieckim oraz nowe możliwości dla socjalistów. Komentując obchody 1 maja, zwrócił uwagę w „Robotniku” z 29 czerwca 1897 r., że święto majowe stało się dla socjalistów polskich okazją do zrobienia przeglądu swoich sił, a więc tym, czym dla partii niemieckiej było powszechne głosowanie. Różnica polegała na tym, „że gdy w Niemczech robotnik, głosujący przy wyborach na socjalistę, na nic się nie naraża i może być tylko sympatyzującym, a nie czynnym bojownikiem socjalizmu - u nas każdy świętujący składa dowód nie tylko należytej świadomości, ale i gotowości do poświęceń" 63 . Piłsudski nie tracił nadziei, że wzrastająca liczba uczestników manifestacji doprowadzi do tego, że Królestwo Polskie będzie widownią przynajmniej tak powszechnego świętowania, jak w Galicji: „Wtedy nadejdzie też czas pomyśleć o bardziej czynnej rozprawie z naszymi wrogami, a przede wszystkim z głównym z nich rządem carskim" 64 .

Wybory w zaborze austriackim nabierały dla Piłsudskiego coraz większego znaczenia, o czym świadczy jego zdziwienie, że w „Przedświcie” nic nie piszą o Galicji: „Takie ciekawe tam się rzeczy dzieją, a u was ani słowa

\footnotetext{
${ }^{61}$ Ibidem, s. 205-206; W. Jędrzejewicz, J. Cisek, op. cit., s. 82.

62 J. Piłsudski, Pisma zbiorowe, t. 1, s. 153-154.

63 Ibidem, s. 166.

${ }^{64}$ Ibidem, s. 167.
} 
o tym”65. 16 stycznia 1897 r. pisał do ZZSP w Londynie: „Później musicie koniecznie dać wyczerpujące sprawozdanie z ruchu przedwyborczego w Galicji, u nas ludzie grubo się tym interesują, a my nic wyczerpującego dać nie możemy sami" 66 .

Od zainteresowania zbliżającymi się wyborami przeszedł do czynów i rozpoczął zbieranie pieniędzy na kampanię wyborczą socjalistów w Galicji do parlamentu wiedeńskiego. 12 grudnia 1896 r. pisał do ZZSP: „Monetę na wybory zbierać zaczniemy teraz, prześlemy ją wprost do nich; czy będzie to wielka moneta - nie wiem, no ale zawsze coś niecoś kapnie”67. W kolejnym piśmie z końca grudnia tego roku donosił: „Do Galileuszy monetę wkrótce wyślemy, na razie tego będzie jakie paręset rubli"68. Wreszcie w liście z 7 stycznia 1897 r. donosił do ZZSP w Londynie: „Posyłamy wam w tym liście 100 rs. Są to sumy, zebrane na wybory w Galicji. Posyłamy te 100 rs. przez was do komitetu Zachodniej Galicji”. Charakterystyczne dla materialnej sytuacji socjalistów było następujące stwierdzenie: „Stanowczo wymagamy, byście nic z tej monety nie buchali i momentalnie wyprawili wraz z listem do Krakowa. Przyznaję się, że wyprawiamy monetę do was z pewną bojaźnią i strachem, aby z tym nie wyszło jakiego kawału przy waszej stałej bryndzy [sic], ale nie róbcie nam z tym ambarasu, będziemy bowiem z czasem zmuszeni zawierać stosunki bezpośrednie z interesantami zagranicznymi" "0s. Ostrzeżenie przed ewentualnym uszczupleniem tej sumy oraz załączenie czystego papieru z pieczątką CKR, z którym należało przesłać pieniądze, świadczy wyraźnie o wadze przywiązywanej do wprowadzenia posłów socjalistycznych do parlamentu austriackiego. Na zarzuty Dębskiego, żeby nie uszczuplać finansów partii i nie przeznaczać zbyt dużych kwot na wybory w Galicji kosztem działalności organizacji w zaborze rosyjskim, Piłsudski tak odpowiedział w liście z 12 lutego 1897 r. do ZZSP:

Na wybory swoich finansów nie szarpiemy wcale, są to składki na ten specjalny cel zbierane na listy. Żadnych naszych instytucji na ten cel nie naciągamy [--]. Co do wyborów, to żałuję, żeśmy akcji nie rozpoczęli wcześniej, zebralibyśmy monety na ten cel znacznie więcej. Teraz ręczę, że moneta na ten cel będzie nam przypływała jeszcze po ukończeniu wyborów. No, ale stało się. Teraz posyłam wam jeszcze 50 fajgli [rubli], które razem z 50 z tej setki, którą wam musiała posłać w tych dniach Kizia [Aleksander

\footnotetext{
${ }^{65}$ Listy Józefa Piłsudskiego, „Niepodległość” 18, 1938, s. 70-71.

66 Ibidem, s. 74.

67 Listy Józefa Piłsudskiego, „Niepodległość” 17, 1938, s. 357.

68 Ibidem, s. 369.

69 Listy Józefa Piłsudskiego, „Niepodległość” 18, 1938, s. 69-70.
} 
Sulkiewicz], wyślijcie do Wschodniej Galicji przy liście stosownym. W tym celu załączam też kartkę z pieczątką. Nie piszę już teraz, żebyście tej monety nie wydali na moje (swoje?) potrzeby, ale i nie przepraszam za to, żem uprzednio o tym pisał ${ }^{70}$.

24 lutego ponownie wsparł finansowo wybory w Galicji: „Kochani! Posyłamy wam: a) 180 r., z nich 60 rs. dla Zachod.[niej] Gal.[icji], 60 dla Wschodniej i 60 dla was. Zapewne przed wyborami już więcej nie poszlemy monety na wybory"71.

O tym, jak wielkie zainteresowanie wzbudzały wybory do V kurii w Austrii wśród socjalistów z zaboru rosyjskiego świadczy fakt, że Leon Wasilewski w lutym 1897 r. specjalnie udał się do Wiednia i do Galicji, aby z bliska obserwować kampanię wyborczą prowadzoną przez socjalistów ${ }^{72}$. Wyniki wyborów przeprowadzonych 11 marca 1897 r. pozwoliły na wzmocnienie sił demokratycznych w parlamencie austriackim. Oprócz 28 posłów chrześcijańsko-społecznych pojawiło się także 14 posłów socjalistycznych, w tym dwóch Polaków (z Krakowa Ignacy Daszyński i ze Lwowa Jan Kozakiewicz ${ }^{73}$ ), sześciu Czechów i siedmiu Niemców, a także dodatkowo Ukrainiec, dr med. Roman Jarosiewicz ${ }^{74}$. Daszyńskiego, który otrzymał w Krakowie prawie 30 tys. głosów, pod nieobecność w parlamencie Viktora Adlera (przegrał on wybory w Wiedniu

70 Ibidem, s. 206.

71 Ibidem, s. 210.

72 A. Próchnik, op. cit., s. 124.

${ }^{73}$ W Jarosławiu kandydat socjalistyczny Kornel Żelaszkiewicz przepadł jedynie z powodu nadużyć władz, zob. W. Najdus, Polska Partia Socjalno-Demokratyczna, s. 200; H. Binder, Galizien in Wien. Parteien, Wahlen, Fraktionen und Abgeordnete im Übergang zur Massenpolitik, Wien 2005, s. 222-225.

${ }^{74}$ Do pierwszych socjaldemokratycznych posłów należeli: Ernst Berner, redaktor w Morawskiej Ostrawie; Peter Cingr, redaktor „Odborné Listy” w Morawskiej Ostrawie; Ignacy Daszyński; Josef Hannich, redaktor „Nordböhmischer Volksbote”, Reichenberg (Liberec); Josef Hybeš, redaktor „Novosti”, Brno; Wilhelm Kiesewetter, redaktor „Freigeist”, Trautenau (Trutnov); Jan Kozakiewicz, kreślarz budowlany, Lwów; Johann Resel, redaktor „Arbeiterwille”, Graz; Eduard Rieger, redaktor „Volksfront”, Brno; Anton Schrammel, redaktor „Gleichheit”, Neunkirchen; Jozef Steiler, redaktor „Sociální Demokrat", Praga; dr Leo Verkauf, doradca prawny spółdzielczych kas chorych, Eger; Karl Vratny, stolarz, Pilzno; Eduard Zeller, sekretarz okręgowej kasy chorych; do klubu socjalistycznego przystąpił później poseł ukraiński Roman Jarosiewicz - L. Brügel, op. cit., s. 308-309; F. Kaufmann, op. cit., s. 34-38, 89; H. Konrad, op. cit., s. 59-60. Pod wpływem apeli PPSD robotnicy polscy ze Śląska Cieszyńskiego oddali swe głosy na czeskiego socjalistę Petra Cingra - W. Najdus, Polska Partia Socjalno-Demokratyczna, s. 193; H. Wereszycki, Historia polityczna Polski 1864-1918, Wrocław-Warszawa-Kraków 1990, s. 152. 
na rzecz chrześcijańskich socjalistów), wybrano przewodniczącym Związku Posłów Socjalistycznych, a jego zastępcami zostali Czech Joseph Hybeš i Niemiec Eduard Zeller ${ }^{75}$.

Piłsudski, który bardzo uważnie obserwował wybory do parlamentu wiedeńskiego, donosił w „Robotniku” z 14 kwietnia 1897 r. w stylu rasowego reportera $\mathrm{w}$ artykule Po wyborach o walnym zwycięstwie „towarzyszy naszych”. „Szerokim echem rozchodziły się u nas odgłosy walki, toczonej za kordonem. Wybory zajęły umysły wszystkich, kto choć cokolwiek wykraczał myślą poza ciasne szranki życia osobistego. Przeżywaliśmy literalnie gorączkę wyborczą, która trawiła podówczas naszych braci galicyjskich, żyliśmy ich nadziejami, odczuwaliśmy ich zawody, oburzaliśmy się i cieszyli razem z nimi"76. Zwrócił uwagę, że wolne wybory w Galicji budziły zainteresowanie bardzo różnych warstw społecznych w Kongresówce. „Pisma były zapełnione wiadomościami o przebiegu walki, a że legalnych pism socjalistycznych nie mamy, wiadomości te najczęściej były skoszlawione stronniczą nienawiścią. Nawet pisma tzw. postępowe, jak «Głos» i «Prawda», w swych korespondencjach z Galicji ze źle tajoną niechęcią spotkały kandydatury socjalistyczne, otaczając natomiast faworami i opieką ludowców, równie chwiejnych i nieokreślonych, jak i nasi postępowcy".

Podkreślił też znaczenie wyborów galicyjskich dla całej Polski. „Niejedno też serce robotnicze zabiło silniej, niejedną pierś podniosło westchnienie ulgi, gdy nareszcie doszła nas radosna wieść o zwycięstwie naszych towarzyszy. Żałowaliśmy tylko, że nie możemy publicznie i jawnie święcić triumf polskiego socjalizmu, nie możemy nawet wprost przesłać naszym bratnim szeregom powinszowania, płynącego z głębi serca". Piłsudski przedstawił dokładnie wyniki wyborów do kurii powszechnego głosowania i znaczenie powstania pierwszej socjalistycznej frakcji w parlamencie austriackim. „Bez wątpienia jest to za mało dla poważnych zwycięstw w prawodawczej działalności parlamentarnej, lecz dosyć dla utrzymania na wodzy łupieżczych apetytów warstw uprzywilejowanych i dla rozbudzenia walką w parlamencie nieświadomych jeszcze mas ludu robotniczego". Przesłał serdeczne życzenia powodzenia w ich pracy, wyrażając dumę, że „wezmą w niej poważny udział nasi posłowie,

75 J. Feldman, Daszyński Ignacy, PSB, t. 4, Kraków 1938, s. 448-454; W. Najdus, Polska Partia Socjalno-Demokratyczna, s. 192-201; eadem, Ignacy Daszyński, s. 127; W. Łazuga, op. cit., s. 146-152; R. Taborski, Polacy w Wiedniu, Wrocław 1992, s. 93-95; J. Buszko, Polacy w parlamencie wiedeńskim 1848-1918, Warszawa 1996, s. 193-195; Von der Donaumonarchie zum vereinten Europa, s. 230-231.

${ }^{76}$ J. Piłsudski, Pisma zbiorowe, t. 1, s. 163-164. 
wybrani wprawdzie przez cząstkę naszych szeregów, lecz występujący w imieniu całego proletariatu polskiego"77.

W niewątpliwym związku z tymi wydarzeniami pozostawało rozpoczęcie w Wiedniu od wiosny 1897 r. działalności sekcji Związku Zagranicznego Socjalistów Polskich z udziałem Leona Wasilewskiego, Maksa Landaua, Władysława i Wacława Studnickich i innych. W duchu PPS przekształcono stowarzyszenie robotnicze „Siła”, poświęcając także wiele miejsca informowaniu opinii publicznej w Wiedniu, m.in. na łamach czasopism „Arbeiter Zeitung” i miesięcznika „Przedświt”, którego redaktorem był Wasilewski ${ }^{78}$.

O docenianiu przez Piłsudskiego instytucji przedstawicielskich świadczy fakt, że interesował się także wyborami socjalistów do parlamentu niemieckiego zapowiadanymi na 1898 r. $^{79}$, o czym pisał w liście z 18 października 1897 r. do ZZSP: „Na przyszłe ich wybory zbierać będziemy ile się da, rozpoczniemy agitację wcześniej, niż z Galicją, więc chyba i zbierzemy więcej" ${ }^{\prime 0}$. Do sprawy powrócił w liście z 3 marca 1898 r. do Centralizacji: „100 rs. wyślijcie od nas do Berlina na wybory, nie jest to wszystko i zapewne przy następujących pieniądzach wyślemy im i liścik jaki z paru serdecznymi słowy. Pieniądze niech pokwitują: «Z Warszawy od Centr. Kom. PPS na wybory»" "1. 28 marca napisał następny list w sprawie wysłania pieniędzy na wybory: „Posyłamy znowu 100 rs., z nich 75 rs. niech Centr[alizacja] przeszle do Berlina na wybory"82. 26 lipca tegoż roku w liście wysłanym z Londynu do Maksymiliana Horwitza w Ostendzie prosił go o przygotowanie kroniki zagranicznej do „Robotnika”, w której znaleźć się miały m.in. sprawy wyborów w Niemczech i we Francji ${ }^{83}$.

77 Ibidem; W. Jędrzejewicz, J. Cisek, op. cit., s. 82-83; W. Pobóg-Malinowski, op. cit., s. 153.

78 A. Próchnik, op. cit., s. 124-125.

79 Chodziło o wybory do parlamentu Rzeszy w czerwcu 1898 r., podczas których socjaliści wystawili w siedmiu okręgach polskich kandydatów wywodzących się z PPS zaboru niemieckiego; zdobyli oni 4537 głosów, lecz żaden z nich nie został wybrany, zob. L. Trzeciakowski, Posłowie polscy w Berlinie 1848-1928, Warszawa 2003, s. 194-195.

${ }^{80}$ Listy Józefa Piłsudskiego, „Niepodległość” 18, 1938, s. 240-241; W. Pobóg-Malinowski, op. cit., s. 153.

${ }^{81}$ J. Piłsudski, Pisma zbiorowe. Uzupełnienia, red. A. Garlicki, R. Świętek, t. 2: 18981914, Warszawa 1993, s. 32.

82 Ibidem, s. 37.

83 Ibidem, s. 54. 
Wobec działalności posłów socjalistycznych

w parlamencie wiedeńskim IX kadencji

(27 marca 1897 - 7 września 1900)

Po wyborach w 1897 r. najliczniejszy klub w parlamencie wiedeńskim utworzyli Czesi (62 posłów). Koło Polskie liczyło 59 posłów, kierowanych przez Apolinarego Jaworskiego, gdyż 13 ludowców i socjalistów, spośród 15 posłów w V kurii w Galicji, nie wstąpiło do Koła, które dotąd gromadziło wszystkich posłów polskich ${ }^{84}$. W ocenie Daszyńskiego był to bardzo ważny fakt, gdyż „obręcz bezwzględnej solidarności posłów polskich pod komendą stańczyków pękła po raz pierwszy; dzień ten zadecydował o niepowodzeniu polityki polskiej w Galicji"85. Natomiast Władysław Studnicki twierdził oskarżycielsko, że „Daszyński był taranem rozbijającym Koło Polskie ku radości wszystkich nieprzyjaciół naszych" ${ }^{\text {"86 }}$. Kazimierz Chłędowski, urzędnik Ministerstwa do spraw Galicji (w latach 1899-1900 minister), miał lepsze zdanie o Daszyńskim: „Na pohybel Kołu Polskiemu muszę przyznać, że Daszyński był jedną z najsympatyczniejszych postaci polskich w Radzie Państwa; człowiekiem talentu, przekonań i sympatycznej powierzchowności"87.

Daszyński prowadził nadzwyczaj aktywną działalność parlamentarną, o czym świadczy fakt, że w 1897 r. 14 razy występował na forum parlamentu i złożył siedem interpelacji, dotyczących m.in. spraw konfiskaty czasopism socjalistycznych, nadużyć w wyborach do Kasy Chorych w Nowym Sączu i Tarnowie. Zwrócił się do ministra obrony krajowej w sprawie kar nakładanych na żołnierzy i podoficerów odwiedzających lokale socjalistyczne. W debacie budżetowej wystąpił przeciw militaryzmowi, a także przeciw antysemityzmowi w polemice z Karlem Luegerem ${ }^{88}$.

Niektóre działania socjalistów galicyjskich spotkały się z pełnym poparciem Piłsudskiego. Tak było wobec podróży nowego cara Rosji Mikołaja II we wrześniu 1897 r. do Wiednia. Czołobitne przyjęcie, jakie mu zgotowano, także z udziałem polskich ministrów, wywołało powszechny sprzeciw. W Galicji i w Wiedniu socjaliści zwoływali zgromadzenia, na których przyjmowano rezolucje, wyrażające „oburzenie i pogardę

${ }^{84}$ H. Wereszycki, Historia Austrii, s. 249-250; J. Buszko, Polacy w parlamencie wiedeńskim, s. 195-199; W. Łazuga, op. cit., s. 127-152; Das österreichische Parlament, Wien 1997, s. 16-18; H. Binder, op. cit., s. 351-356.

${ }^{85}$ I. Daszyński, op. cit., s. 127.

${ }^{86}$ M. Zdziechowski, Widmo przyszłości, Warszawa 1999, s. 116.

87 K. Chłędowski, Pamiętniki, t. 2: Wiedeń 1881-1901, Wrocław 1951, s. 334-335.

${ }^{88}$ W. Najdus, Ignacy Daszyński, s. 127-132; J. Buszko, Polacy w parlamencie wiedeńskim, s. 217; Von der Donaumonarchie zum vereinten Europa, s. 231-233. 
za wyrzucanie pieniędzy robotników na przyjęcie najwstrętniejszego despoty". Podobne stanowisko zajął Piłsudski, który przeprowadził druzgocącą krytykę polityki ugody w związku z wizytą cara Mikołaja II nie tylko w Wiedniu, ale także w Warszawie ${ }^{89}$.

W innych jednak sprawach dochodziło do konfliktów. Krytycy oskarżyli Daszyńskiego, że trybunę parlamentarną w Wiedniu wykorzystuje do oczerniania rządów polskich w Galicji oraz rządu premiera Badeniego, określanego przezeń jako reakcyjny i podtrzymujący władzę szlachty. Gdy Badeni przystąpił do rozszerzenia praw językowych Czechów w administracji Królestwa Czeskiego, socjaliści przyłączyli się do ataków nacjonalistów niemieckich na kompromisową inicjatywę premiera, hamując i dezorganizując obrady parlamentu oraz przyczyniając się do obalenia rządu ${ }^{90}$. Na nic zdało się wystąpienie Daszyńskiego na VI kongresie ogólnopartyjnym obradującym w Wiedniu od 6 do 12 czerwca 1897 r., dotyczące działalności parlamentarnej socjalistów, w tym stosunku do rozporządzeń językowych ${ }^{91}$.

Postępowanie Daszyńskiego wywołało krytykę także w środowiskach socjalistycznych z Kongresówki. Pojawiły się wątpliwości, czy należało przyłączać się do obstrukcji, zainicjowanej z szowinistycznych pobudek przez niemieckich nacjonalistów, i czy wypadało socjalistom torpedować reformę rozszerzającą narodowe uprawnienia Czechów, nawet realizowaną na drodze administracyjnej, a nie parlamentarnej. Wątpliwości nie rozwiały argumenty Daszyńskiego, że nieustanne naruszanie uprawnień parlamentu za pomocą rozporządzeń rządowych podkopywało konstytucję i godziło w prawa obywatelskie. „Przedświt” krytycznie ocenił Daszyńskiego, gdyż obalił on rząd premiera rodaka, w którym zasiadali jeszcze trzej inni ministrowie narodowości polskiej ${ }^{92}$. Do krytyków postępowania Daszyńskiego należał także Piłsudski ${ }^{93}$. W liście z 5 grudnia 1897 r. apelował do CKR, aby posłowie socjalistyczni z Galicji - Daszyński i Kozakiewicz - częściej pisali do „Przedświtu” i wytłumaczyli swoje postępowanie w Wiedniu. „Mamy miliony zarzutów z powodu nich z różnych stron - ich sojusz z Niemcami szowinistycznymi dla wszystkich stawia znak zapytania. Różne o tym chodzą gadki do bajki, że Ignac jest

89 J. Piłsudski, Pisma zbiorowe, t. 1, s. 150-153, 177-179; W. Pobóg-Malinowski, op. cit., s. 128-130 W. Jędrzejewicz, op. cit., s. 28-29.

90 W. Łazuga, op. cit., s. 153-201; J. Buszko, Posłowie polscy w parlamencie wiedeńskim, s. $198-211$.

91 W. Najdus, Polska Partia Socjalno-Demokratyczna, s. 208-209.

92 W. Najdus, Ignacy Daszyński, s. 133; J. Buszko, Polacy w parlamencie wiedeńskim, s. $210-211$.

${ }^{93}$ J. Gaul, Czarno-żółty miraż, s. 24-25. 
na żołdzie u [Georga] Schoenerera i [Karla Hermanna] Wolfa włącznie. Dosyć powiedzieć, że imiennik Timura [Aleksander Więckowski] zaniepokoił się tymi zarzutami i na gwałt prosił, by w «Rob.[otniku]» dać jakieś tłumaczenie. Przypuszczamy, że lepiej by to było zrobione w «Przed.[świcie]»"94. Stanisław Wojciechowski, komentując to zdanie, dopisał: „nawarzyli nam piwa, niech więc choć w «Przedświcie» bronią swego stanowiska, bo dalibóg trudno tu pyskiem «filozofować» w ich obronie" 95 .

26 stycznia 1898 r. Piłsudski poruszył sprawę odezwy Daszyńskiego do wyborców w sprawie działalności parlamentarnej posłów socjalistycznych w Wiedniu: „Odezwę Daszka, jeżeli nie przedrukuje «Przed.[świt]», co sądzę byłoby najlepsze, to - naturalnie - dajcie 4000 egz. przy «Przed.[świcie]»" 96 . Uznał ją jednak za niewystarczającą i nieprzekonywającą, skoro ponownie skrytykował stanowisko posłów socjalistycznych w parlamencie wiedeńskim. 15 lutego 1898 r. w liście do „Przedświtu” napisał:

Faktem niezaprzeczonym jest, że Daszyński i Kozakiewicz uważani są w całej Polsce za przedstawicieli polskiego socjalizmu - i, jako tacy, są sądzeni, błędy więc ich i omyłki składane są powszechnie na karb całego ruchu, a więc i naszego. Tymczasem Daszyński i Kozakiewicz dotychczas nie potrafili nawet zaznaczyć, że leżą im na sercu interesa ruchu polskiego, przede wszystkim zaś i zawsze byli tylko przedstawicielami ruchu austriackiego. I gdyby jeszcze te liczenie się tylko z ruchem austriackim, a nie polskim, nie doprowadziło ich do pewnych kolizji z naszymi interesami byłoby pół biedy, nie zrobiliby dla nas nic dobrego, lecz i szkody by żadnej nie przynieśli, lecz ich sojusz z Wolfami i C-o, od których mogą się odżegnywać, ile im się podoba, a pomimo to fakty ten sojusz stwierdzały, ich taktyka, która pozwoliła, by w walce z Badenim na pierwsze miejsce właśnie wypłynęła sprawa językowa, a nie jakaś inna, więcej godna polskich socjalistów, wszystko to na pewien czas być może, ale zraziło do socjalistów sfery nie socjalistyczne zupełnie, lecz sympatyzujące z nami i uławiające nam przez swą sympatię robotę. Teraz to zacichło, lecz kto wie, czy jeszcze jedna taka „zwycięska” kampania parlamentarna, jeszcze jedno „Hoch Daszyński”, pomieszane z "Wacht am Rhein”, nie utrudni nam znacznie i tak nie łatwego położenia, a da jeszcze parę ataków w łapy nie tylko patriotów, lecz nawet i dalszej naszej prawicy. Pomijamy tu najzupełniej kwestię, o ile taktyka ich była zgodna z interesami nawet austriackiego proletariatu, chociaż zdaniem niektórych z nas (pomiędzy innymi i moje) i tu zgody nie było. Naturalnie, nie

${ }^{94}$ Listy Józefa Piłsudskiego, „Niepodległość” 18, 1938, s. 352-353.

${ }^{95}$ Ibidem, s. 353, przyp. 29.

96 Ibidem, s. 364; W. Pobóg-Malinowski, op. cit., s. 154. 
spodziewaliśmy się, by „galicyjscy” posłowie od razu mogli godnie reprezentować socjalizm „polski”, ale nie oczekiwaliśmy takiego nieliczenia się z naszymi potrzebami ${ }^{97}$.

\section{Dalej pisał równie krytycznie:}

Myśli te, które zapewne tow. Witoldowi [Jodko-Narkiewiczowi - J.G.] przyszły samodzielnie, wyrażaliśmy również nieraz w naszych [?] listach i rozmowach z nim, i, przyznamy się, cieszyliśmy się, gdy w „Przed.[świcie]” pojawiły się artykuły, inkriminowane przez towarzyszy galicyjskich. Być może, że nie wpłyną one na dalsze postępowanie Dasz.[yńskiego] i Kozak. [iewicza], bo ci zdaje się są bardzo dumni ze swych zwycięstw i w niektórych kawałkach „Naprzodu” i „Robot.[nika]” daje się spostrzec nieświadome jak dotychczas wycofywanie się z niektórych przynajmniej pozycji, osiągniętych przez „zwycięstwa”. W każdym jednak razie artykuły te w „Przed. [świcie]" zdejmują w części w oczach naszej opinii publiczności odpowiedzialność naszą za czyny nie nasze. Wobec tego, nie robiąc na was żadnego nacisku, gdyż, naturalnie, możecie w tym wypadku mieć całkiem inne zdanie, wolelibyśmy, żeby ton artykułów w „Przed.[świcie]”, omawiających te sprawy, nie był tak chwalącym i panegirycznym, jak w 1 numerze. Przyjmijcie pod uwagę, że po otrzymaniu właśnie 1 numeru namyślaliśmy się, czy nie machnąć do was oficjalne nasze oświadczenie, wyrażając solidarność w pewnej mierze z artykułami „Swój” i Witolda w 10-tym. A sprawiłoby to zapewne jeszcze przykrzejsze wrażenie i wywołało jeszcze większy gwałt, niż artykuły w „Przed.[świcie]” 98 .

Nie brakowało też innych punktów spornych dotyczących Galicji. Daszyński wystąpił przeciw autonomii królestw i krajów koronnych należących do monarchii austriackiej. Jego zdaniem, wyodrębnienie zacofanej Galicji, będącej łupem podczas rozbiorów Polski, z uprzemysłowionej Austrii, posiadającej liczniejszy proletariat i silniejszą partię socjalistyczną, oddałoby ją w ręce magnatów i utrwaliłoby rządy „szlachetczyzny". Należało zatem wcześniej przeprowadzić demokratyczne reformy polityczne i dopiero potem wysuwać postulat autonomii terytoriów narodowych ${ }^{99}$. Podobne stanowisko zajął Wasilewski w artykule

${ }^{97}$ Listy Józefa Piłsudskiego, „Niepodległość” 18, 1938, s. 376-378; W. Jędrzejewicz, J. Cisek, op. cit., s. 92; W. Pobóg-Malinowski, op. cit., s. 154.

${ }^{98}$ Listy Józefa Piłsudskiego, „Niepodległość” 18, 1938, s. 378. Artykuły W. Jodko-Narkiewicza w „Przedświcie”, krytykujące udział polskich posłów socjalistycznych w opozycji przeciwko Badeniemu, spowodowały z kolei protesty działaczy socjalistycznych zaboru austriackiego i sprzeciw w sekcjach ZZSP w Galicji, ibidem, przyp. 30; zob. Listy Józefa Piłsudskiego, „Niepodległość” 19, 1939, s. 414-416.

99 W. Najdus, Polska Partia Socjalno-Demokratyczna, s. 208-209. 
Dwie autonomie w numerze 6 „Przedświtu” z czerwca 1898 r. Autor postawił w nim pytanie, czy Austria jest socjalistom potrzebna i udzielił na nie negatywnej odpowiedzi. Nie widział on w Austrii siły, która przywróci byt niepodległej Polsce i odrzucił koncepcję austro-polską. Nie spodziewał się także, aby wojna pomiędzy Austrią a Rosją przyniosła szczęśliwe rozwiązanie sprawy polskiej. Austria była potrzebna o tyle, o ile gwarantowała proletariatowi polskiemu rozwój, niemożliwy w innych zaborach ${ }^{100}$.

Piłsudski odniósł się krytycznie do tej sprawy w liście z 11 lipca 1898 r. do Witolda Jodko-Narkiewicza w Bernie, zachęcając go do napisania artykułu o autonomii galicyjskiej: „Sądziłbym, że to tym bardziej jest potrzebne, że artykuły Osarza [Leona Wasilewskiego - J.G.] lub Kozaka [Jana Kozakiewicza - J.G.] mogą u nas zrobić swoje, tj. albo zasiać wśród ludzi niekrytycznych błędne pojęcia, albo też zniechęcić do nas tych, którzy już raz nieszczęsną sprawą językową niegdyś byli zniechęceni" ${ }^{101}$. O autonomii galicyjskiej pisał także 29 lipca 1898 r. do Kazimierza Kelles-Krauza. Poinformował w nim, że

stosunek Centr.[alizacji], tak zarówno i redakcji „Przedświtu” do spraw galicyjskich uważam za bardzo fałszywy. U nas w kraju już przed tym istniało grube niezadowolenie z galileuszy z powodu sprawy językowej i obstrukcji parlamentarnej, więc gdy w „Przed.[świcie]” zostały umieszczone artykuły „Swój” i w 10 N[umerze]. byliśmy wszyscy bardzo radzi, że choć słówko prawdy doszło do uszu naszych posłów i galicyjskich towarzyszy. Nowa redakcja uważała za stosowne postępować wręcz przeciwnie - solidaryzować się ze wszystkim, co posłowie lub Galicjanie zrobią. Jeszcze z kraju po pierwszych numerach tego roku pisałem do redakcji w imieniu CKR, że artykuły zeszłoroczne zostały umieszczone w „Przed.[świcie]” z naszego upoważnienia, że galicyjska robota odbija się na naszym położeniu i szkodzi powodzeniu naszej pracy, że więc wolelibyśmy nie widzieć w „Przed. [świcie]” artykułów zaprzeczających dotychczasowym wypowiedzeniom się zeszłorocznym. Teraz jednak mamy znowu drugie wydanie tej sprawy w kwestii autonomii. I wstępny artykuł, i koresp.[ondencja] Kozak.[iewicza] w 6 numerze wzbudzą zapewne wśród naszych w kraju grube niezadowolenie i dodam od razu - zupełnie słusznie. Już w jednym liście z kraju od towarzysza CKR otrzymałem w odpowiedzi na 6 numer propozycję, bym postawił tamę zgalicjanieniu „Przedśw.[itu]” i Zw.[iązku]. Osobiście jestem zdania, że artykuły takie u nas będą bardzo szkodliwe - od pożądania opieki c.k. urzędnika w obronie od szlachty rodzimej krok jeden do obozu Różyczki [Róży Luksemburg - J.G.]. Wobec tego wypowiedziałem to wszystko Os.[arzowi]. Otrzymałem odpowiedź, iż jest to jego przekonanie, że autonomia

100 A. Próchnik, op. cit., s. 134-135.

101 J. Piłsudski, Pisma zbiorowe. Uzupetnienia, t. 2, s. 48. 
zaszkodzi Galicji i ruchowi soc.[jalistycznemu] - i trudno mu pisać wbrew przekonaniu, że jednak gotów jest dać miejsce we „Przed.[świcie]” głosom przeciwnym ${ }^{102}$.

Krytykę socjalistycznych posłów galicyjskich utrudniły jednak wprowadzone od wiosny 1898 r. przez władze w zachodniej Galicji stan oblężenia i sądy doraźne ${ }^{103}$. Motywując to rozruchami antysemickimi, rozprawiono się z działaczami socjalistycznymi, zamykając wiele stowarzyszeń socjalistycznych i zawieszając prasę. Piłsudski zdawał sobie sprawę z dwuznaczności sytuacji: „Na razie na tym stanęło, wątpię jednak, by obecnie można było w tej kwestii prowadzić polemikę, w której z konieczności trzeba było ganić to lub owo w postępowaniu Galicjan. Przy stanie oblężenia i prześladowaniach obecnych trzeba milczeć. Chciałbym więc tylko, żebyś w listach swoich do Centr.[alizacji] zwracał na tę stronę baczniejszą uwagę i przeciwdziałał owemu "zgalicjanieniu»"104.

Wydarzenia te nie powstrzymały Piłsudskiego przed dalszym konsekwentnym dążeniem do demokratycznej Polski. Znalazło to swój wyraz liście z 29 lipca 1898 r. napisanym w Londynie do Kelles-Krauza w Paryżu w sprawie opracowania rozdziału o polityce w Sprawie robotniczej: „W rozdziale powinno się zawierać wytłumaczenie tego, co znaczy wolność polityczna, parę słów o rządzie reprezentacyjnym i powsz[echnym] prawie głosowania, następnie wytłumaczenie, na co ta wolność jest nam potrzebna i stwierdzenie ścisłej zależności ekon[omicznych] i polit[ycznych] interesów proletariatu, nareszcie cel obecnej walki - niezależna Polska ze zdobyciem maksimum swobód i krótkie uzasadnienie tego celu"105.

Przemiany w socjalistycznym ruchu w Galicji ułatwiły prowadzenie „polityki wspólnej”. Na VI zjeździe w Wiedniu w czerwcu 1897 r. austriacka partia socjalistyczna zmieniła swoją strukturę organizacyjną. Scentralizowana partia przeobraziła się w federację partii narodowych (polskiej, austriackiej, czeskiej, serbskiej, włoskiej i ukraińskiej), które łączyła wspólna ogólnoaustriacka egzekutywa oraz zjazd partyjny ${ }^{106}$.

102 Listy Józefa Piłsudskiego, „Niepodległość” 20, 1939, s. 129-130; W. Pobóg-Malinowski, op. cit., s. 154.

103 Zob. E. Bobrowski, Stan wyjątkowy w Galicji wr. 1898 (Urywek z pamiętnika), „Niepodległość" 13, 1936, s. 442-446; Pamiętnik Hermana Diamanda, zebrany z wyjątków listów do żony, Kraków 1932, s. 36-39.

104 Listy Józefa Piłsudskiego, „Niepodległość” 20, 1939, s. 129-130.

105 J. Piłsudski, Pisma zbiorowe. Uzupetnienia, t. 2, s. 56.

106 L. Brügel, op. cit., s. 335-343; H. Konrad, op. cit., s. 61: „Es bestand also keine gemeinsame österreichische sozialdemokratische Partei mehr, sondern eine geeinigte Partei der österreichischen Sozialdemokratie, welche aus den verschiedenen Nationalitäten zusammengesetzt ist". 
Rzecznicy kursu narodowego w galicyjskiej socjaldemokracji doprowadzili do przekształcenia partii krajowej w partię polską, lansując nazwę Polska Partia Socjalno-Demokratyczna Galicji i Śląska (PPSD), o czym przesądził V zjazd krajowy we wrześniu 1897 we Lwowie. Podkreślenie narodowego charakteru partii znalazło wyraz w uchwale o dążeniu socjalistów polskich wszystkich trzech zaborów do zjednoczenia Polski i jej niezależności państwowej ${ }^{107}$. Włączenie do jej nazwy „Śląska” związane było z nasilającą się agitacją socjalistyczną w wysoko uprzemysłowionym rejonie cieszyńskim ${ }^{108}$. Jak twierdził Daszyński w marcu 1898 r. w Izbie Posłów Rady Państwa, socjaldemokracja jest partią „poliglotyczną, gdzie Czech spokojnie zasiada koło Polaka i Niemca, walczącą o równe uprawnienie językowe, ale bez rozniecania waśni narodowych"109.

Na zjeździe berneńskim socjaldemokracji austriackiej w 1899 r. delegacja polska złożyła ważną deklarację w kwestii narodowościowej, stwierdzając, że „socjaliści polscy wszystkich trzech zaborów pracują wytrwale nad usunięciem tej strasznej krzywdy narodu polskiego i dążą do zjednoczenia w przyszłości wszystkich trzech zaborów w jedną politycznie i narodowo niezależną całość, do wolnej i zjednoczonej Ojczyzny"110. Takie stanowisko PPSD, zbliżone do PPS, sprowokowało atak Róży Luksemburg na polskich socjalistów na międzynarodowym zjeździe socjalistycznym w Paryżu we wrześniu 1900 r. W ich obronie wystąpił Viktor Adler, stwierdzając: „Protestujemy przeciwko temu, aby nasza jednolicie braterska organizacja cierpiała na takich napaściach, robiących wrażenie oszczerstw. Nie wierzcie, jakoby nasi polscy towarzysze byli «nacjonalistami». Oni są tak samo dobrze międzynarodowymi socjalnymi demokratami, jak i każdy z nas"111.

Adler chwalił „naszych Polaków” za wspaniałe postępowanie i „całkowicie zaskakujące sukcesy”. Szczególnie pozytywnie ocenił Daszyńskiego: „Daszyński rzeczywiście jest wybitnym człowiekiem, gdybyśmy go nie mieli w parlamencie, źle by nam się działo. To jest także jego zasługa w dużym stopniu, że nie tylko z Polakami, ale także z o wiele bardziej trudnymi Czechami, tak dobrze sobie radzimy. Jest człowiekiem, z którym można rozmawiać, a takich nie mamy niestety zbyt

107 W. Najdus, Polska Partia Socjalno-Demokratyczna, s. 210-215; W. Najdus, Zygmunt Marek. Prawnik i polityk 1872-1931, Warszawa 1992, s. 21-22; J. Holzer, op. cit., s. 64-65.

108 Na Śląsku Cieszyńskim Polacy, rywalizujący z Czechami i Niemcami, utrzymywali ścisłe kontakty z Galicją. Na tym terenie działał socjalista Tadeusz Reger. W. Najdus, Polska Partia Socjalno-Demokratyczna, s. 210-215; P. Wandycz, op. cit., s. 417-418.

109 J. Buszko, Polacy w parlamencie wiedeńskim, s. 219-220.

110 L. Wasilewski, op. cit., s. 69.

111 Ibidem, s. 84-85. 
wielu"112. Adler widział w Daszyńskim przedstawiciela zachodniej partii socjaldemokratycznej „na Wschodzie”. Jego poważanie i wpływy miały dla socjaldemokratów w Austrii istotne znacznie i dlatego poparł w liście z 30 listopada 1899 r. do Augusta Bebla wydawanie w Krakowie dziennika socjalistycznego „Naprzód”, prosząc go o wsparcie tej inicjatywy ${ }^{113}$.

Wypowiedź Adlera sytuowała Daszyńskiego dokładnie tam, gdzie chciał widzieć socjalistów polskich Piłsudski, który nigdy nie miał wątpliwości co do przynależności Polski do cywilizacji Zachodu. Już w 1895 r. stawiał siebie i towarzyszy na posterunku dziejowym, na najdalej na Wschód wysuniętej placówce socjalizmu europejskiego, w historycznej roli obrońcy Zachodu od zaborczego i reakcyjnego caratu ${ }^{114}$. Ocena Adlera mogła być źródłem satysfakcji. Obrany przez Piłsudskiego i Daszyńskiego antyrosyjski i prozachodni kierunek działań sprawił, że w niewiele lat później, 10 listopada 1912 r., znaleźli się razem w Komisji Tymczasowej Skonfederowanych Stronnictw Niepodległościowych, a w sierpniu 1914 r. wystąpili zbrojnie u boku Austro-Węgier przeciw imperium carskiemu.

Jak wynika z powyższych ustaleń, Piłsudski miał w latach 1897-1900, a także później pozytywny stosunek do parlamentaryzmu w monarchii habsburskiej ${ }^{115}$. W odrodzonej Rzeczypospolitej, pełniąc urząd Tymczasowego Naczelnika Państwa, zorganizował bardzo szybko, bo już 26 stycznia 1919 r., pierwsze wolne wybory. Uważał bowiem, że głównym filarem ładu i podstawą prawną państwa powinien być parlament. W lutym 1919 r. podporządkował się wybranym przez naród reprezentantom i złożył swój urząd na ręce Konstytuanty. Obserwując jednak polską „,sejmokrację" w działaniu, stał się wobec niej bardzo krytyczny. Wszechwładza sejmu, która zastąpiła dyktaturę Naczelnika Państwa, przyniosła wiele negatywnych zjawisk, zwłaszcza przewagę interesów partyjnych nad państwowymi, z czym Piłsudski nie chciał się pogodzić. Wnioski, które

112 V. Adler, Briefwechsel mit August Bebel und Karl Kautsky, gesammelt und erläutert von Friedrich Adler, Wien 1954, s. 34; R. Taborski, op. cit., s. 94; W. Najdus, Ignacy Daszyński, s. 127.

113 V. Adler, op. cit., s. 34.

114 J. Piłsudski, Pisma zbiorowe, t. 1, s. 95; W. Pobóg-Malinowski, op. cit., s. 124; W. Jędrzejewicz, op. cit., s. 23. Współgrało to z przekonaniami wielu socjalistów niemieckich, m.in. Augusta Bebla i Fryderyka Engelsa, o konieczności odepchnięcia Rosji na wschód, oderwania od niej Polski i wskrzeszenia jej jako demokratyczne państwo. W. Pobóg-Malinowski, op. cit., s. 97-98.

115 Zob. J. Gaul, Posłowie polscy do Rady Państwa w Wiedniu wobec ruchu niepodległościowego w okresie zawieszonego parlamentu (sierpień 1914 - maj 1917), „Studia Humanistyczno-Społeczne" 7, 2013, s. 13-36. Autor przygotowuje obecnie artykuł dotyczący stosunku Piłsudskiego do parlamentaryzmu austriackiego i posłów galicyjskich do Rady Państwa w Wiedniu w latach 1901-1914. 
wyciągnął, doprowadziły do zamachu majowego w 1926 r. i do ograniczenia parlamentaryzmu w sanacyjnej Polsce.

\section{Streszczenie}

Kontakty Józefa Piłsudskiego z socjalistami z zaboru austriackiego rozpoczęte w 1892 r. doprowadziły do przezwyciężenia nieporozumień i nawiązania współpracy na gruncie walki o niepodległość Polski. Piłsudski zapoznał się z konstytucyjnym systemem monarchii habsburskiej i docenił możliwości legalnej walki o prawa robotników oraz prowadzenia polityki antyrosyjskiej i niepodległościowej także za pomocą „oręża parlamentaryzmu”. Po rozpoczęciu batalii socjalistów galicyjskich o wejście do parlamentu wiedeńskiego w V kurii głosowania powszechnego Piłsudski udzielił im wsparcia, m.in. przesyłając środki finansowe. W wyniku wyborów przeprowadzonych 11 marca 1897 w Izbie Posłów Rady Państwa IX kadencji (27 marca 1897 - 7 września 1900) pojawili się po raz pierwszy posłowie socjalistyczni, w tym z Galicji Ignacy Daszyński i Jan Kozakiewicz. Piłsudski wspierał ich działalność, lecz potrafił zdobyć się na krytykę Daszyńskiego, m.in. za obalenie rządu Kazimierza Badeniego. Piłsudski widział socjalistów polskich na najdalej na Wschód wysuniętej placówce socjalizmu europejskiego, w historycznej roli obrońcy Zachodu od zaborczego i reakcyjnego caratu. Obrany przez Piłsudskiego i Daszyńskiego antyrosyjski i prozachodni kierunek działań sprawił, że w 1912 r. znaleźli się razem w Komisji Tymczasowej Skonfederowanych Stronnictw Niepodległościowych, a w sierpniu 1914 walczyli u boku Austro-Węgier przeciw imperium carskiemu. Oceniając postać Piłsudskiego, nie można widzieć w nim tylko samotnika z Sulejówka, autora zamachu majowego i dyktatora zwalczającego parlamentaryzm oraz posłów opozycji, gdyż w młodości był zwolennikiem konstytucjonalizmu, parlamentaryzmu oraz podstawowych praw obywatelskich, które wcielił w życie jako Naczelnik Państwa w latach 1918-1922.

\section{The Stance of Józef Piłsudski Regarding the Election to the Austrian Parliament and Activities of the Polish Socialist Deputies of the Ninth Term (1897-1900)}

Józef Piłsudski's contacts with socialists from Galicia (the Austrian share of the partitioned Polish lands), first established in 1892, made it possible to put an end to disagreement and start cooperation for the independence of Poland. Having acquainted himself with the rudiments of the constitutional system of the Habsburg monarchy, Piłsudski appreciated the possibility of a legal struggle for workers' rights as well as pursuing an anti-Russian and pro-independence policy also with a "parliamentary weapon". After the Galician socialists began their campaign to be elected to the Vienna parliament, Piłsudski provided his support for them, inter alia in the form of financial assistance. When, after the election of 
11 March 1897, the first socialist deputies gained seats in the House of Deputies of the Imperial Council of the Ninth Term (27 March 1897 - 7 September 1900), including Ignacy Daszyński and Jan Kozakiewicz from Galicia, Piłsudski supported their actions. However, he was not afraid openly to criticize Daszyński, for example, for the deposing of Kazimierz Badeni's cabinet. Piłsudski envisaged Polish socialists at the easternmost outpost of European socialism, in a historic role of the defenders of the West against aggressive and reactional tsarism. The anti-Russian and pro-Western course adopted by Piłsudski and Daszyński resulted in the membership of them both, in 1912, in the Temporary Coordinating Commission of Confederated Independence Parties, and in August 1914 in their fight against Russia at the side of Austria-Hungary. When assessing the figure of Piłsudski, one should see not only the recluse from Sulejówek, the author of the May coup, or the dictator combating parliamentarianism and persecuting opposition deputies, for in his youth he was an advocate of constitutionalism, parliamentarianism, and basic civil rights which he put into practice in Poland as the Head of State in 1918-1922.

Translated by Grażyna Waluga

\section{Bibliografia}

Adler Viktor, Briefwechsel mit August Bebel und Karl Kautsky, gesammelt und erläutert von Friedrich Adler, Wiener Volksbuchhandlung, Wien 1954.

Ajnenkiel Andrzej, Romana Dmowskiego i Józefa Piłsudskiego spór o Polskę, w: Do niepodległości 1918, 1944/45, 1989. Wizje, drogi, spetnienie, red. Wojciech Wrzesiński, Wydawnictwo Sejmowe, Warszawa 1998, s. 201-223.

Ardelt Rudolf Gustav, Sozialdemokratie und Bürgerliche Öffentlichkeit. Überlegungen zum Hainfelder Parteitag, w: Politik und Gesellschaft im alten und neuen Österreich. Festschrift für Rudolf Neck zum 60. Geburtstag, t. 1, red. Isabella Ackerl, Walter Hummelberger, Hans Mommsen, Verlag für Geschichte und Politik, Wien 1981, s. $214-238$.

Ardelt Rudolf Gustav, Vom Kampf um Bürgerrechte zum „Burgfrieden”. Studien zur Geschichte der österreichischen Sozialdemokratie 1888-1914, Verlag für Gesellschaftskritik, Wien 1994.

Binder Harald, Galizien in Wien. Parteien, Wahlen, Fraktionen und Abgeordnete im Übergang zur Massenpolitik, Verlag der Österreichischen Akademie der Wissenschaften, Wien 2005.

Bobrowski Emil, Stan wyjątkowy w Galicji w r. 1898 (Urywek z pamiętnika), ,Niepodległość" 13, 1936, s. 442-446.

Brügel Ludwig, Geschichte der österreichischen Sozialdemokratie, t. 4, Wiener Volksbuchhandlung, Wien 1923.

Buszko Józef, Józef Piłsudski w Krakowie 1896-1935, KAW, Kraków 1990.

Buszko Józef, Polacy w parlamencie wiedeńskim 1848-1918, Wydawnictwo Sejmowe, Warszawa 1996.

Chłędowski Kazimierz, Pamiętniki, t. 2: Wiedeń 1881-1901, oprac. Antoni Knot, Ossolineum, Wrocław 1951. 
Das österreichische Parlament, Parlamentsdirektion, Wien 1997.

Daszyński Ignacy, Pamiętniki, t. 1, Nakładem Związku Robotniczych Stowarzyszeń Spółdzielczych „Proletariat”, Kraków 1925.

Dziadzio Andrzej, Monarchia konstytucyjna w Austrii (1867-1914). Władza - obywatel prawo, Księgarnia Akademicka, Kraków 2001.

Feldman Józef, Daszyński Ignacy, PSB, t. 4, Kraków 1938, s. 448-454.

Garlicki Andrzej, Józef Piłsudski 1867-1935, Znak, Kraków 2009.

Gaul Jerzy, Czarno-zótty miraż. Sprawa Józefa Piłsudskiego w monarchii habsburskiej 1896-1918, Agencja Wydawnicza CB, Warszawa 2018.

Gaul Jerzy, Między Austria a Polska.. Posłowie galicyjscy w parlamencie wiedeńskim, w: Viribus Unitis? Polscy parlamentarzyści w monarchii habsburskiej 1848-1918, red. Barbara Górska, Międzynarodowe Centrum Kultury, Kraków 2012.

Gaul Jerzy, Posłowie polscy do Rady Państwa w Wiedniu wobec ruchu niepodległościowego w okresie zawieszonego parlamentu (sierpień 1914 - maj 1917), „Studia Humanistyczno-Społeczne" 7, 2013, s. 13-36.

Grodziski Stanisław, Franciszek Józef I, Ossolineum, Wrocław-Warszawa-Kraków 1978.

Grodziski Stanisław, Sejm Krajowy Galicyjski 1861-1914, t. 1-2, Wydawnictwo Sejmowe, Warszawa 1993.

Grodziski Stanisław, W Królestwie Galicji i Lodomerii, Wydawnictwo Literackie, Kraków 1976.

Holzer Jerzy, PPS. Szkic dziejów, Wiedza Powszechna, Warszawa 1977.

Jędrzejewicz Wacław, Cisek Janusz, Kalendarium życia Józefa Piłsudskiego 1867-1935, t. 1: 1867-1916, LTW, Kraków-Łomianki 2006.

Jędrzejewicz Wacław, Józef Piłsudski. 1867-1935. Życiorys, LTW, Łomianki 2014.

Kaufmann Fritz, Sozialdemokratie in Österreich. Idee und Geschichte einer Partei von 1889 bis zur Gegenwart, Amalthea, Wien-München 1978.

Kołakowski Leszek, Główne nurty marksizmu, t. 2, PWN, Warszawa 2009.

Konrad Helmut, Nationalismus und Internationalismus. Die österreichische Arbeiterbewegung vor dem Ersten Weltkrieg, Europa Verlag, Vienna 1976.

Kuprian Hermann, An der Schwelle zum 20. Jahrhundert - Staat und Gesellschaft vor dem Erstem Weltkrieg, w: Österreich im 20. Jahrhundert, t. 1: Von der Monarchie bis zum Zweiten Weltkrieg, red. Rolf Steininger, Michael Gehler, Böhlau Verlag, Wien-Köln-Weimar 1997, s. 9-62.

Listy Józefa Piłsudskiego, oprac. Władysław Pobóg-Malinowski, Leon Wasilewski, „Niepodległość” 13-20, 1935-1939.

Litwin-Lewandowska Dorota, 0 polską rację stanu w Austrii. Polacy w życiu politycznym Austrii w okresie monarchii dualistycznej (1867-1918), Wydawnictwo UMCS, Lublin 2008.

Łazuga Waldemar, „Rzady polskie” w Austrii. Gabinet Kazimierza hr. Badeniego 1895-1897, Wydawnictwo Naukowe UAM, Poznań 1991.

Najdus Walentyna, Ignacy Daszyński 1866-1936, Czytelnik, Warszawa 1988.

Najdus Walentyna, Polska Partia Socjalno-Demokratyczna Galicji i Ślaska 1890-1919, PWN, Warszawa 1983.

Najdus Walentyna, Zygmunt Marek. Prawnik i polityk 1872-1931, IH PAN, Warszawa 1992. 
Pamiętnik Hermana Diamanda, zebrany z wyjątków listów do żony, Towarzystwo Uniwersytetu Robotniczego (TUR), Kraków 1932.

Pijaj Stanisław, Między polskim patriotyzmem a habsburskim lojalizmem. Polacy wobec przemian ustrojowych monarchii habsburskiej (1866-1871), Historia Iagellonica, Kraków 2003.

Piłsudski Józef, Pisma zbiorowe, t. 1-10, Instytut Józefa Piłsudskiego, Warszawa 1937-1938.

Piłsudski Józef, Pisma zbiorowe. Uzupetnienia, red. Andrzej Garlicki, Ryszard Świętek, t. 1: 1886-1897, KAW, WSiP, Warszawa 1992; t. 2: 1898-1914, KAW, WSiP, Warszawa 1993.

Pobóg-Malinowski Władysław, Józef Piłsudski 1867-1914, LTW, Łomianki 2015.

Próchnik Adam, Leon Wasilewski w polskim ruchu socjalistycznym, „Niepodległość" 16, 1937, s. 107-163.

Protokoły Koła Polskiego w wiedeńskiej Radzie Państwa (lata 1867-1868), oprac. i wstęp Zbigniew Fras, Stanisław Pijaj, Historia Iagellonica, Kraków 2001.

Schefbeck Günther, Parlament wielonarodowy, w: Viribus Unitis? Polscy parlamentarzyści w monarchii habsburskiej 1848-1918, red. Barbara Górska, Międzynarodowe Centrum Kultury, Kraków 2012, s. 40-55.

Suleja Włodzimierz, Józef Piłsudski, Ossolineum, Wrocław 1995.

Taborski Roman, Polacy w Wiedniu, Ossolineum, Wrocław 1992.

Trzeciakowski Lech, Posłowie polscy w Berlinie 1848-1928, Wydawnictwo Sejmowe, Warszawa 2003.

Urbankowski Bohdan, Józef Piłsudski. Marzyciel i strateg, Zysk i S-ka, Warszawa 2014. Von der Donaumonarchie zum vereinten Europa. 20 Reichsratsabgeordnete die Geschichte schrieben, red. Andreas P. Pittler, Marie-Louise Janota, Wieser Verlag, Klagenfurt-Wien-Ljubjana-Sarajevo 2003.

Wandycz Piotr, Pod zaborami 1795-1918, PIW, Warszawa 1994.

Wasilewski Leon, Zarys dziejów Polskiej Partii Socjalistycznej. W związku z historią socjalizmu polskiego w trzech zaborach i na emigracji, Spółdzielnia Wydawniczo-Księgarska „Nowe Życie”, Warszawa 1924.

Wereszycki Henryk, Historia Austrii, Ossolineum, Wrocław-Warszawa-Kraków 1986. Wereszycki Henryk, Historia polityczna Polski 1864-1918, Ossolineum, Wrocław-Warszawa-Kraków 1990.

Zdrada Jerzy, Organizacja i stanowisko Koła Polskiego w wiedeńskiej Radzie Państwa (18611862), „Zeszyty Naukowe Uniwersytetu Jagiellońskiego. Prace Historyczne” 1963, 12, s. 62-76.

Zdziechowski Marian, Widmo przyszłości, Stowarzyszenie Kulturalne Fronda, Warszawa 1999.

Biogram: Jerzy Gaul - dr hab., profesor nadzwyczajny w Archiwum Głównym Akt Dawnych w Warszawie. Zainteresowania badawcze: historia XIX/XX w., kontakty austriacko-polskie, polonika, I wojna światowa, Józef Piłsudski; kontakt: jerzygaul@hoga.pl. 